\title{
The Role of Imaging in the Management of Renal Masses
}

\section{Jiaali Ratna Sari}

Puskesmas Janti, Malang City, Indonesia

Email: jiaalyrs@gmail.com

\begin{abstract}
The widespread availability of cross-sectional imaging is responsible for the increased detection of small, usually asymptomatic renal masses. More than $50 \%$ of renal cell carcinomas (RCCs) represent incidental findings on noninvasive imaging. Multimodality imaging, including conventional US, contrast-enhanced US (CEUS), multiparametric CT and MRI (mpMRI) is essential in diagnosing and characterizing renal masses, but also provides information regarding its prognosis, therapeutic management, and follow-up. In this review, the imaging data for renal masses that urologists require for accurate treatment planning will be discussed. The roles of US, CEUS, CT and mpMRI in the detection and characterization of renal masses, RCC staging and follow-up of treated or untreated local RCCs will be presented. The role of percutaneous image-guided ablation in the management of RCC will also be reviewed.
\end{abstract}

Keywords: Renal neoplasm, Renal cell carcinoma, Multimodal imaging, Minimally invasive treatment 


\section{Introduction}

The wide availability of cross-sectional imaging plays an important role in improving the detection of small, usually asymptomatic renal masses [1, 2, 3, 4, 5, 6, 7]. Most renal masses are benign cysts. However, renal cell carcinoma (RCC) is often detected incidentally, and the patient's prognosis is better in these cases $[8,9,10,11]$. Accurate noninvasive characterization of renal masses is important to ensure appropriate treatment planning $[1,2,3,4,5,6,7]$.

The first step when detecting a renal mass is to differentiate between a benign cyst and a solid mass. Most cystic renal masses are benign, and when malignant, they are often indolent. The Bosniak classification of cystic renal lesions was recently updated [12, 13]. Although validation is required, a major modification incorporates cystic masses detected on MRI or US, establishing a definition for previously unclear imaging terms and allowing for a greater reduction in the proportion of renal cystic masses [12, 13].

Although their incidence is lower compared to cystic masses, up to $90 \%$ of solid renal tumors are malignant, and RCC accounts for $90 \%$ of renal malignancies [2],[3]. The most common benign solid renal masses are angiomyolipoma (AML) and renal oncocytoma [2, 3, 4, 5, 6, 7]. Visible lean AML (fatpoor AML) accounts for about $5 \%$ of AML $[2,3,4,5,6,7]$.

The prognosis of RCC is mainly related to tumor stage, histologic subtype, and nuclear grade $[2,3,4]$. Preoperative RCC staging and anatomic information are essential to guide treatment decisions $[14,15]$. The histologic classification of RCC is also important, given the prognostic and therapeutic implications of the histologic subtypes of RCC. Clear cell RCC, papillary RCC and chromophobic RCC are the most common histologic subtypes of RCC [16]. RCC assessment represents another important prognostic factor. The four-tier WHO/ISUP (International Society of Urological Pathology) scoring system has replaced the traditional Fuhrman scoring system [17].

Surgery, including radical nephrectomy or partial nephrectomy is the recommended treatment for localized RCC $[2,18]$. The elderly and patients with comorbidities and incidental small renal masses have low RCC-specific mortality and significant competing cause mortality, therefore ablative techniques and active surveillance may represent alternative treatment options [2,18,19, 20]. Active surveillance defined as early monitoring of tumor size by serial imaging, with delayed intervention provided for tumors that show clinical progression during follow-up, is a safe management option, not compromising oncological outcome [2, 18, 21, 22].

Imaging is essential in the diagnosis and characterization of renal masses, providing valuable information regarding staging, prognosis, therapeutic management, and follow-up [7, 8, 9, 23, 24, 25]. US can easily characterize most incidental renal masses as simple cysts, but cannot always differentiate between benign and malignant solid renal tumors [26]. Contrast-enhanced ultrasonography (CEUS) has emerged as a valuable adjunct tool, useful in the differential diagnosis between solid renal masses and pseudotumors, and between complex renal cysts and solid renal tumors [26, 27, 28, 29]. CT is the gold standard for characterization of renal masses and for staging RCC [14, 30]. Multiparametric MRI (mpMRI) is a useful adjuvant tool in the armamentarium diagnosis of renal masses [31, 32].

In this review, we comment on the role of multimodality imaging, including US, CEUS, CT and mpMRI in the management of renal masses. In particular, the role of imaging modalities in the characterization of cystic renal masses, differentiation between the histologic phenotype of RCC and common benign renal tumors, assessment of RCC, staging of RCCs and follow-up of treated or untreated local RCCs were reviewed. The role of minimally invasive, image-guided RCC curative management is discussed. A urologist's perspective on the requirements regarding radiological reports of renal masses is presented.

\section{What urologists expect from radiologists}

Despite the reported excellent sensitivity and specificity for cross-sectional imaging in detecting, occasionally, small $(<2 \mathrm{~cm})$ renal masses, usually endophytic renal tumors may be missed [33]. Potential implications for the treating urologist may exist, if the radiological report misses the diagnosis.

The probability of a renal mass becoming malignant is inversely proportional to its size. As more than $50 \%$ of newly diagnosed renal masses are less than $3 \mathrm{~cm}$ in size, it is clear that the urologist wants to confirm the histology of the mass, before deciding on treatment. Unfortunately, histologic characterization based on imaging criteria alone is not always possible. Understandably, this is a difficult task, as even renal tumor biopsy can be nondiagnostic in up to $8 \%$ of cases, in centers of excellence [33]. Fat-poor AML, small papillary RCC, and renal oncocytoma pose diagnostic challenges for radiologists and pathologists. 
Imaging is cardinal for staging RCC. Table 1 shows theRCC classification system Tumor-NodeMetastatic (TNM)[2,15]. The upper border of the inferior vena cava neoplastic thrombus guides the operation, as a thrombus reaching the thorax and heart requires a cardiothoracic surgeon and special anesthetic requirements. Precise mapping of regional lymph node extension will help the surgeon remove palpable lymph nodes. Removal of the ipsilateral adrenal gland is possible if imaging implies invasion by a neighboring tumor. The number, size, and location of distant metastases will predict the technical feasibility of metastasectomy and help decide whether or not to proceed with cytoreductive nephrectomy [2].

Table 1. TNM RCC classification system [15]

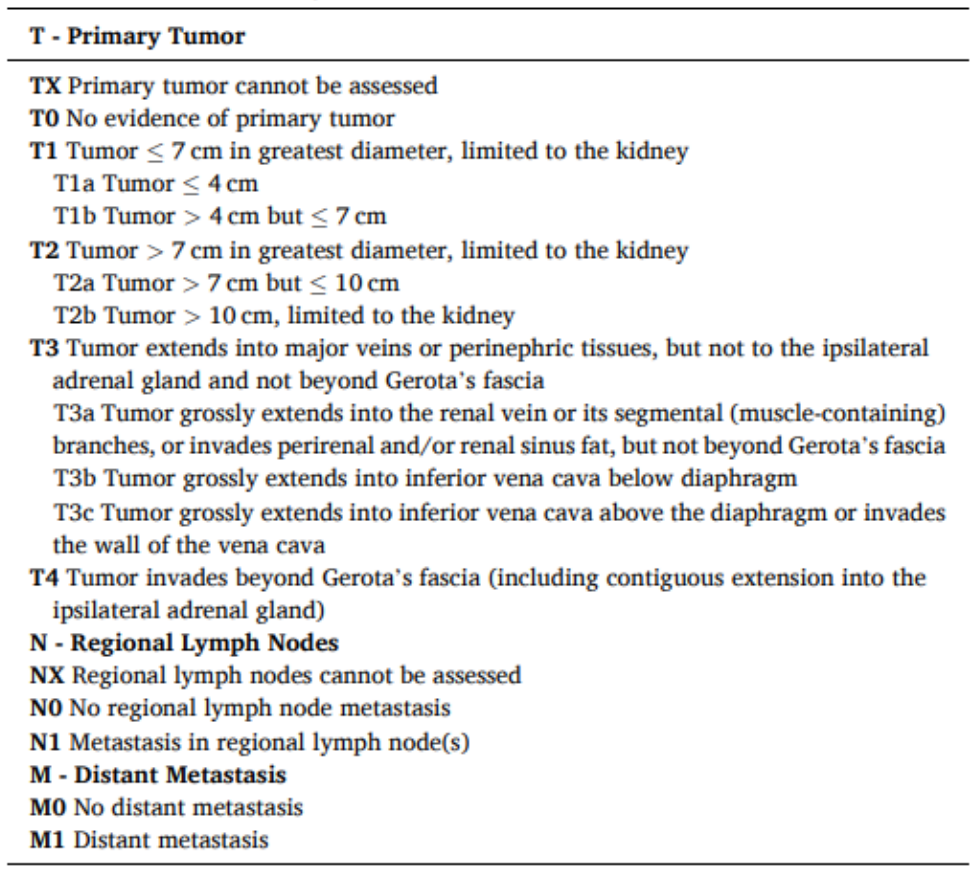

Although a tumor size of $4 \mathrm{~cm}$ is an acceptable limit for partial nephrectomy, other factors may allow partial resection of a larger tumor or dictate radical removal of a smaller tumor. Therefore, information regarding the relationship of the tumor to the collecting system, its surroundings to the renal hilus and the endophytic or exophytic nature of the tumor, may determine the difficulty of performing a partial nephrectomy. Imaging plays an important role in providing the above information, predicting the impending difficulties of the operation.

Various nephrometric scores (RENAL, Padua, c-index) have been used to measure this expected difficulty [34]. RENAL nephrometry score, assigning tumors to a score depending on points collected from (R)adius tumor, (E)xophytic/endophytic nature, (N)earness to the collecting system or sinuses, (A)interior (a)/posterior(p) descriptor, and (L)location relative to the polar line. Various publications have confirmed the correlation of KIDNEY nephrometry scores with surgical decision making, surgical complications, postoperative functional outcome, histological factors such as stage, grade, and cancerspecific survival rate [34].

During a partial nephrectomy, the kidney tumor must be identified and resected. This requires removal of perinephric fat, which can be tedious at times. Imaging can predict this difficulty by measuring perinephric fat thickness, particularly medial and posterior perinephric fat, and reporting perinephric fat stranding [35]. Equally important is the position of the kidneys in relation to the thoracic cage, especially for open surgery. Information regarding the vascular anatomy, and in particular, the origin, number, division, and course of the renal arteries and veins is also important [36].

Imaging provides the urologist with much of the information needed for treatment planning, therefore, radiology reports are invaluable and should be provided, preferably in a structured format (Table 2) [36].

Table 2. Recommended CT report templates for preoperative assessment of solid renal masses, suspected or proven to represent RCC [36] 


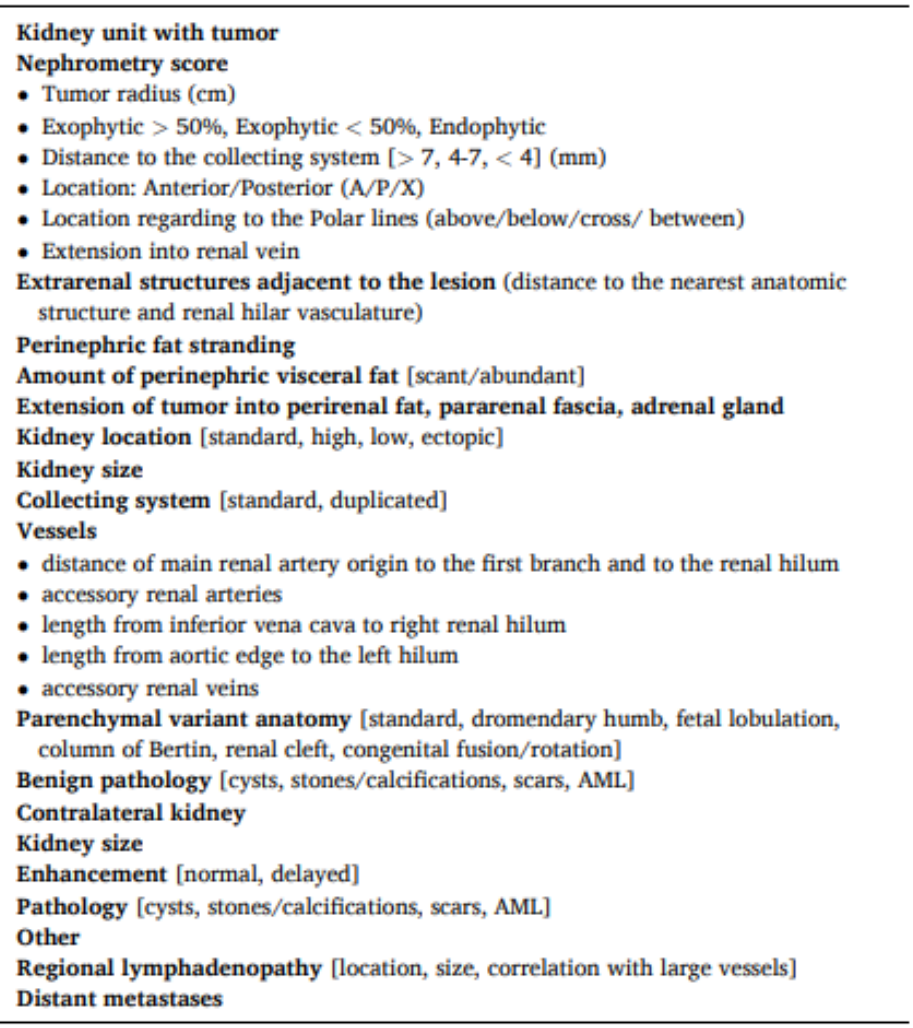

\section{Ultrasonography/Contrast-Enhanced Ultrasonography}

Ultrasonography is the first-line imaging modality for investigation of suspected renal disease $[26,27,28,29]$. US can reliably differentiate between cystic and solid renal lesions and can characterize complex minimally renal cysts [28]. US is recommended for the assessment of homogeneous indeterminate, hyperdense renal masses, incidentally found on CT, measuring 20-70HU on unenhanced images or more than $20 \mathrm{HU}$ on contrast-enhanced single-phase images [6]. These lesions often represent benign hemorrhagic/proteinaceous cysts and can be safely characterized by US, with reported sensitivity and specificity of $81.8 \%$ and $92.9 \%$, respectively [27]. US also remains the primary imaging modality for the early detection and evaluation of solid renal tumors [28]. However, this technique is not always able to accurately differentiate between benign and malignant solid renal tumors [26,28,29].

CEUS with its lack of nephrotoxicity, absence of ionizing radiation, and ability to evaluate the pattern of enhancement, can accurately characterize many renal lesions, without the need for CT or MRI $[26,27,28,29]$. The main renal applications include differentiation between solid and pseudotumor renal tumors, characterization of complex cystic renal masses, characterization of indeterminate renal masses and follow-up of non-surgically treated renal masses [29].

After injection of the ultrasound contrast agent, the renal arteries and main branches were elevated first, followed rapidly by the segmental, interlobar, arcuate and interlobular arteries. Subsequently, complete cortical enhancement was seen (cortical phase, 15-30 s), followed by medullary enhancement (parenchymal phase, in which the cortex and medulla increased homogeneously, $25 \mathrm{~s}-4$ min). Since the ultrasound contrast agent is not excreted by the kidneys, no excretory phase is obtained $[37,38,39,40,41]$.

CEUS is highly recommended to differentiate between renal and pseudotumor tumors (prominent Bertin column, dromedary or splenic hump, persistent fetal lobulation and adjacent areas of renal parenchyma with cortical scarring, showing compensatory hypertrophy), not characterized by conventional US, with an accuracy of up to $95 \%$ [26, 29]. The criterion for diagnosing a pseudotumor is the demonstration of the same pattern of enhancement as the surrounding parenchyma in all phases (Fig. 1) $[26,29,41]$. In contrast, enhancement of most solid renal tumors differs from that of the surrounding renal parenchyma, with differences in the degree or distribution of enhancement in at least one phase of 
contrast enhancement [29, 41, 42]. Solid renal tumors do not show a specific perfusion pattern, therefore their accurate characterization by CEUS is often impossible [23, 40, 41, 43, 44, 45, 46].

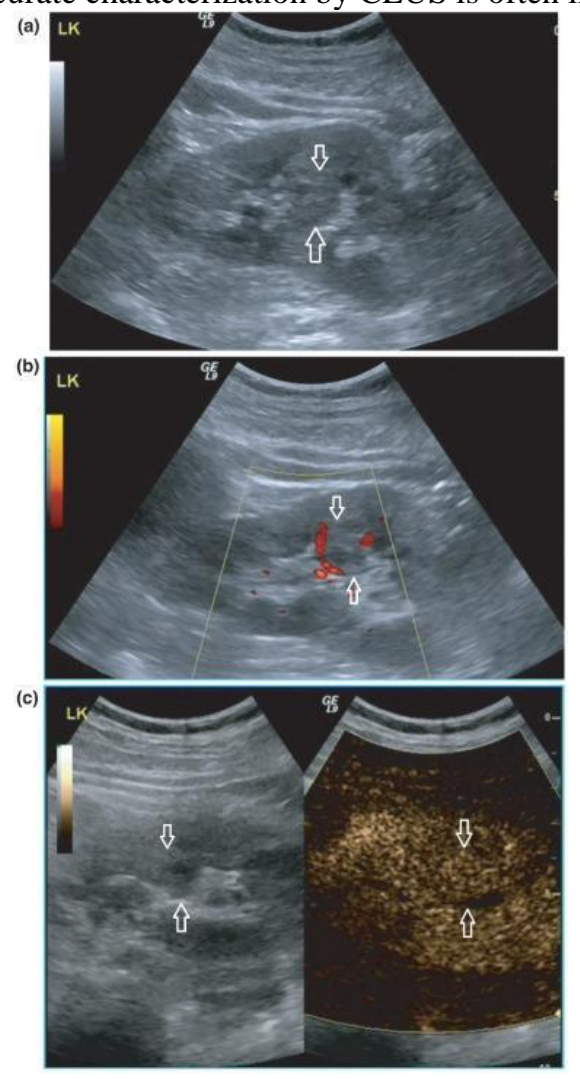

Figure 1. Sagittal (a) grayscale and (b) power Doppler images depicting a solid left renal lesion (arrows) in the interpolar region, mainly isoechoic, when compared to normal renal parenchyma. The mass seems to replace the surrounding blood vessels. After injection of ultrasound contrast agent (c) the lesion (arrow) shows the same enhancement as the remaining renal parenchyma, a finding indicating the presence of a renal pseudotumor. (Source: Dr. DD. Kokkinos).

CEUS can be used to characterize complex cystic renal masses, with accuracy comparable to CT and MRI and reports a concordance rate between the three imaging techniques of approximately $90 \%$ (Fig. 2) [26, 29, 47, 48, 49, 50, 51]. In addition, CEUS has been reported to be more sensitive than CT in demonstrating minimal wall and/or septal enhancement and solid, increasing components in complex cystic renal masses [26, 29, 51, 52]. CEUS is also recommended for non-surgical follow-up of complex cystic kidney lesions [26, 29, 53].

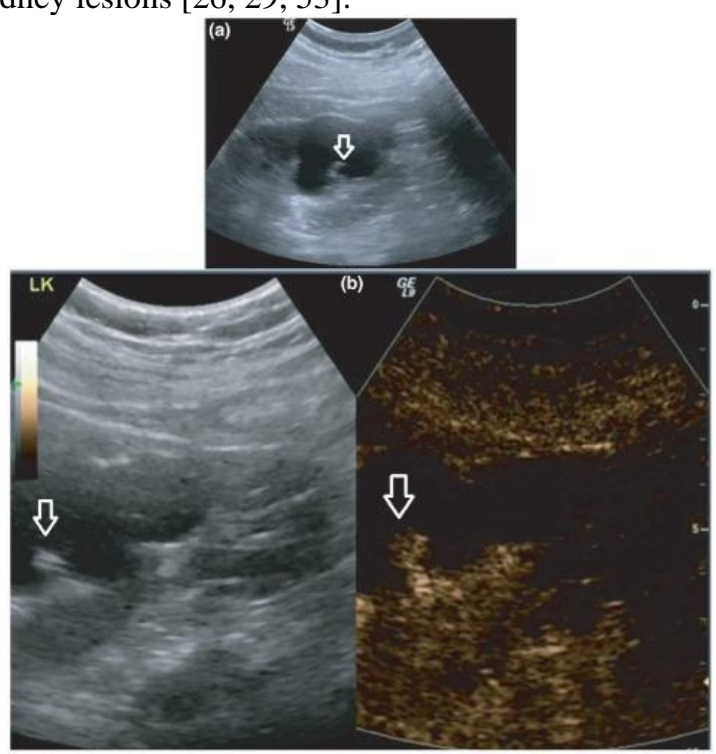


Figure 2(a) US Grayscale image showing a cystic lesion of the right kidney with irregular internal septal thickening (arrows). (b) The contrast-enhanced US display shows an increase in this section (arrows); therefore, the lesion was characterized as Bosniak class III. (Source: Dr. DD. Kokkinos).

CEUS has an important role in the characterization of indeterminate renal lesions, including avascular renal masses, without the typical US findings of simple cysts, complex renal cysts and masses with equivocal CT enhancement or indeterminate CT findings $[6,26,27,28,29,54,55,56]$. In a retrospective study, CEUS had a sensitivity of $100 \%$, specificity of $95 \%$, a positive predictive value (PPV) of $94.7 \%$, and a negative predictive value (NPV) of $100 \%$ in the characterization of an indeterminate renal mass [55]. Follow-up CEUS is also recommended in this case [29].

CEUS can highlight renal vein invasion by RCC on initial evaluation, as arterial thrombus vascularity distinguishes soft thrombus from neoplastic, with sensitivity, specificity, PPV, NPV and accuracy reported of $83 \%, 96 \%, 71 \%, 98 \%$ and $94 \%$, respectively. respectively [14, 27, 29, 57]. Finally, CEUS is helpful in post-ablation RCC follow-up, enabling detection of intralesional enhancement, indicative of residual or recurrent tumor, with sensitivity, specificity, PPV, NPV, and overall accuracy of $96.6 \%$, $100 \%, 100 \%, 95.8 \%$, and $98.1 \%$, respectively $[18,29,58]$.

Table 3 main clinical indications for Color Doppler US and CEUS.

\section{Clinical indications}

The differential diagnosis between solid kidney tumor and pseudotumor

\section{Characterization of solid kidney tumors}

The difference between cystic and solid renal masses is a

Characterization of complex cystic renal mass

RCC post-ablation
Color Doppler US Finding

may be non-specific

Often nonspecific Color Doppler has limitations in assessing neoplastic invasion of renal veins in RCC

limitation in assessing the possibility of perfusion in echogenic cysts

limitations in assessing possible perfusion of septa and/or cyst nodules

no role

\section{Contrast-enhanced Finding}

Renal tumor vasculature differs from normal parenchyma, at least in one phase post contrast/pseudotumor increases parallel to renal parenchyma in all phases

Often nonspecific increased neoplastic renal vein thrombus/soft thrombus shows lack of enhancement

solid hypovascular renal tumors are increased, even slightly / debris not superior to CT/MRI in diagnosing cystic RCC

depicting increased wall/septum and/or $n$ odule accuracy equal to or higher than CT for the classification of cystic lesions of kidney, according to the criteria of Bosniak

to confirm the results of the treatment of the same accuracy with CT / MRI post-ablation area that enhances the contrast is considered tumor residual or recurrent

Nevertheless, the widespread use of CEUS in daily practice is questionable. Continuing training, experience, revising the Bosniak classification, additional research to include CEUS in clinical urology guidelines and new technologies, such as, fusion imaging can improve the diagnostic accuracy of the technique, ensure its safety, and confirm its role in the management of renal masses [59, 60, 61, 62$]$.

\section{Computed Tomography}

Contrast-enhanced CT (CECT) represents the gold standard imaging technique for the detection and characterization of renal masses $[1,2,3,4,5,6,7,23,24,25,30,63,64,65]$. The renal CT protocol consists of an unenhanced phase, combined with one or more contrast phases, namely a corticomedullary phase (40-70sec), a nephrographic phase $(100-120 \mathrm{sec})$ and a delay-excretory phase (7-10min) [66] . 
The nephrographic phase is optimal for detection of RCC, as tumor contrast clearance becomes visible, against the homogeneously increasing renal parenchyma [30,67,68]. The corticomedullary phase can be helpful in subtypes of RCC, as clear cell RCC increases rapidly in this phase [66].

CECT is the modality of choice for evaluation of cystic renal masses [12, 13, 69, 70, 71, 72]. Table 4 shows the CT characteristics of a renal cystic mass based on the recent Bosniak classification [12, 13]. A homogeneous renal mass measured between $-10 \mathrm{HU}$ and $+20 \mathrm{HU}$ on unenhanced CT corresponds to a simple benign cyst, without the need for additional imaging. Homogeneous hyperdense lesion measuring more than 70HU on non-contrast CT, suggesting a benign hemorrhagic cyst or protein cyst [6]. Lesions, either homogeneous or inhomogeneous in the range of 20-70HU, are considered indeterminate and require further evaluation [6]. The most commonly used method to characterize indeterminate renal masses, including cystic and solid renal lesions, is CECT [5,6]. Increasing solid renal tumors or increasing components in the cystic renal mass (Fig. 3) are highly suggestive of malignancy [65]. A difference of at least $10 \mathrm{HU}$ between unenhanced and CECT has been proposed to differentiate renal cysts from solid masses [6]. However, more conservative values, such as 15-20HU are often used to calculate mean partial volume artifacts [73].

Table 4.Classification of Bosniak Cystic Renal Mass, Version 2019 [12,13].

Category

I

II

IIF

III

I V
CT

cystic mass well-defined, homogeneous, watery density $(-10$ to $+20 \mathrm{HU})$, smooth, thin walls $(\leq 2 \mathrm{~mm})$ that may enlarge, absence of septa and/or calcification

well-defined mass, smooth, thin-walled $(\leq 2 \mathrm{~mm})$

cystic mass, few (1-3) thin septa $(\leq 2 \mathrm{~mm})$; walls and septa may increase; calcification of any type

hyperdense homogeneous mass $(\geq 70 \mathrm{HU})$ on homogeneous unenhanced CT homogeneous nonenhancing mass > $20 \mathrm{HU}$ on CT renal mass protocol; may havecalcification

homogeneous mass -10 to $+20 \mathrm{HU}$ on nonenhanced CT homogeneous mass 21$30 \mathrm{HU}$ on portal phase CT

homogeneous hypodense mass, too small to be characterized

cystic mass, smooth, minimal $(3 \mathrm{~mm})$ thickening of walls and/or septa, or many $(\geq 4)$ fine, thin increasing septa cystic mass, thickened ( $\geq 4 \mathrm{~mm}$ ) walls and/or septa, or increased nodules: convex protrusions arising from walls and/or septa, thickened irregularly $(\leq 3 \mathrm{~mm})$, with blunt margins

cystic mass, one or more increasing nodules: convex protrusion, arising from walls and/or septa, $4 \mathrm{~mm}$, with blunt edges,

\section{Findings MRI Findings}

of the well-defined cystic mass, homogeneous, hyperintense $\mathrm{T} 2$ signal, similar to cerebrospinal fluid, smooth, thin-walled $(\leq 2 \mathrm{~mm})$ that may enlarge, absence of septa and/or calcification

well-defined mass, smooth, thin wall $(\leq 2 \mathrm{~mm})$

of cystic mass, few (1-3) thin ( $\leq$ $2 \mathrm{~mm}$ ) contrast-enhancing septa or other non-enhancing septa; may contain calcifications of any kind

, very hyperintense T2 signal, similar to cerebrospinal fluid

homogeneous, highly hyperintense fat suppression T1 signal, equal to or 2.5 times higher than normal renal parenchyma

of cystic mass, smooth, minimal (3mm) thickening of walls and/or septa, or multiple $(\geq 4)$ smooth, thin increasing septa

cystic mass, T1 signal hyperintense heterogeneous fat suppression

cystic mass, thickened $(\geq 4 \mathrm{~mm})$ walls and/or septa, or increased nodules: convex protrusions arising from walls and/or septa, thickened irregularly $(\leq 3 \mathrm{~mm})$, with margins blunt

cystic mass, one or more nodules increasing: convex protrusion, arising from wall and/or septa, $4 \mathrm{~mm}$, 
with blunt edges, or in various sizes, with sharp edges
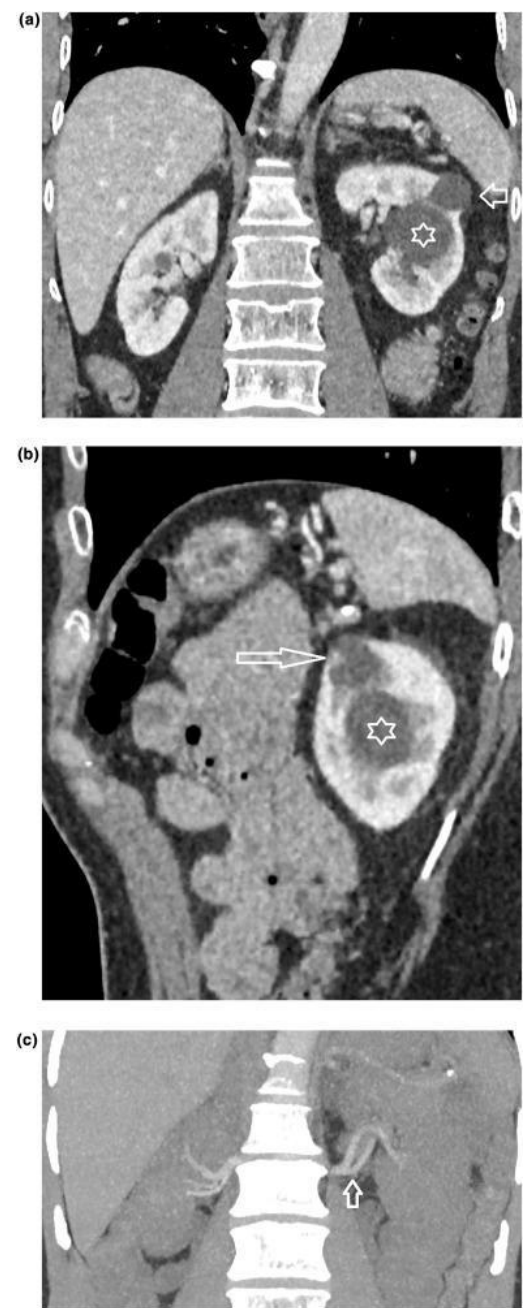

Figure 3. Clear cell RCC of left kidney. (a) Coronal and (b) sagittal contrast-enhanced CT images during the corticomedullary phase depicting a $<50 \%$ exophytic left kidney cystic lesion (arrows), with a $5 \mathrm{~mm}$ contrast-enhancing nodule (long arrow, b, Bosniak grade IV). Left simple benign renal cyst (asterisk). (c) Coronal three-dimensional maximum intensity projection reconstruction image showing the distance from the origin of the left renal artery to the first branch (arrows).

Since CT is considered the gold standard for detecting renal masses, the accuracy of the technique in detecting renal tumors is difficult, based on literature data $[30,74,75]$. In a small retrospective study $(\leq 4 \mathrm{~cm})$ of indeterminate renal mass, the accuracy of CECT in predicting the diagnosis of RCC was 79.4\% [74]. In addition, CT evaluation of small renal masses $(\leq 1.5 \mathrm{~cm})$ may be problematic, due to lesion pseudoenhancement and partial volume mean artifacts, which limit the assessment of contrast enhancement $[76,77,78]$.

CT findings related to lesion homogeneity and enhancement pattern were reported to correlate with the histologic subtype of RCC [30,79, 80, 81]. The typical clear cell RCC was markedly increased in the corticomedullary phase $(114 \pm 44 \mathrm{HU})$, with rapid washout in the nephrographic phase $(66 \pm 24 \mathrm{HU})$ $[30,79]$. Large clear cell RCCs are often heterogeneous, due to necrosis and/or cystic degeneration [79]. Papillary RCCs are usually small, homogeneous and hypovascular, with a weak increase in the corticomedullary phase, up to $20 \mathrm{HU}[30,68]$. No increase is seen in up to $25 \%$ of papillary RCC, and further evaluation with CEUS or mpMRI is suggested to verify the presence of an increasing solid tumor $[30]$.

Chromophobe RCC and renal oncocytoma have similar histologic and imaging features [31, 32, 82, 83, 84]. Therefore, differential diagnosis is often difficult and histological exploration may be required (Fig. 4) [7, 31, 32]. Peripheral location, presence of a central stellate scar or increased spokewheel and inversion of segmental enhancement are common findings for both entities [7, 31, 32, 82, 83, 
84, 85, 86, 87, 88]. Most fat-poor AML is hyperdense on unenhanced CT, increasing homogeneously after contrast administration [30,63]. However, differentiation between fat-poor AML and RCC with CT alone is often difficult and further evaluation by mpMRI, biopsy, or even surgical resection may be necessary $[30,63,89,90,91]$.
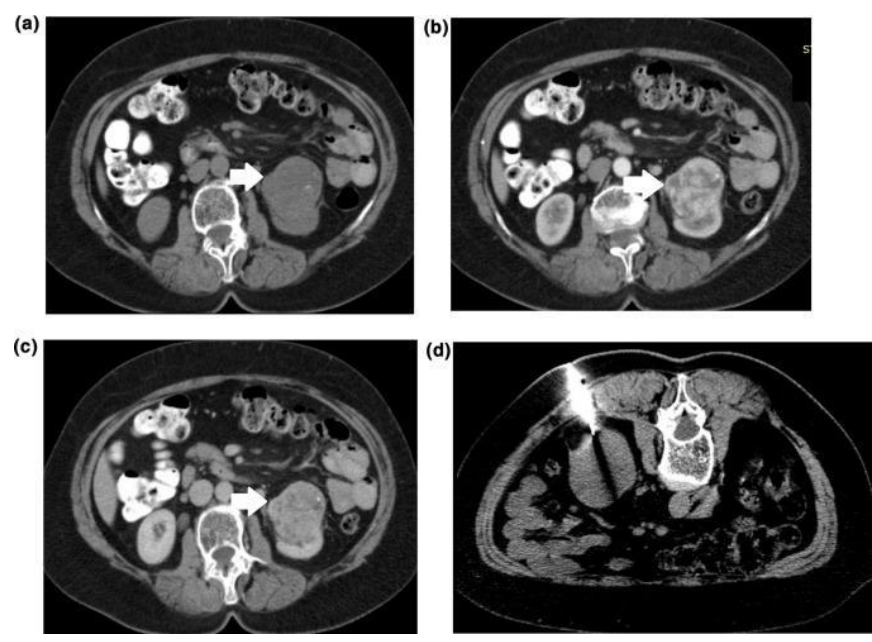

Figure 4. Clear cell RCC in women with a history of breast cancer. (a) Unenhanced axial CT shows a left renal mass (arrow). The lesion had a CT density especially similar to that of normal renal parenchyma and small calcifications. (b) In the corticomedullary phase, the lesion (arrow) shows strong and heterogeneous enhancement, with a washout effect in the nephrographic phase (c). (d) Kidney tumor biopsy revealed clear cell RCC.

Recently, dual-energy CT with contrast has been reported to improve the diagnostic performance of CT in the characterization of renal masses, with a sensitivity and specificity greater than $95 \%$ in the evaluation of renal tumors $[92,93]$. New techniques, including CT perfusion, CT texture analysis and CT-based radiomics can provide important additional information in the characterization of renal masses $[94,95,96,97,98,99]$

To date, multimodality imaging has not always been able to accurately characterize renal masses. found incidentally, primarily, a small renal mass $(\leq 4 \mathrm{~cm})[100]$. Percutaneous renal tumor biopsy has been shown to help avoid surgery in up to $33 \%$ of cases initially thought to be malignant, based on imaging [101]. Indications for renal tumor biopsy in local RCC include small renal masses, when the results may change management (Fig. 5) and masses with findings suggestive of lymphoma, metastases, infectious or inflammatory lesions [102]. Kidney tumor biopsy is also recommended prior to thermal ablation, as a separate procedure or shortly before treatment [102]. A biopsy can be performed under US or CT guidance.
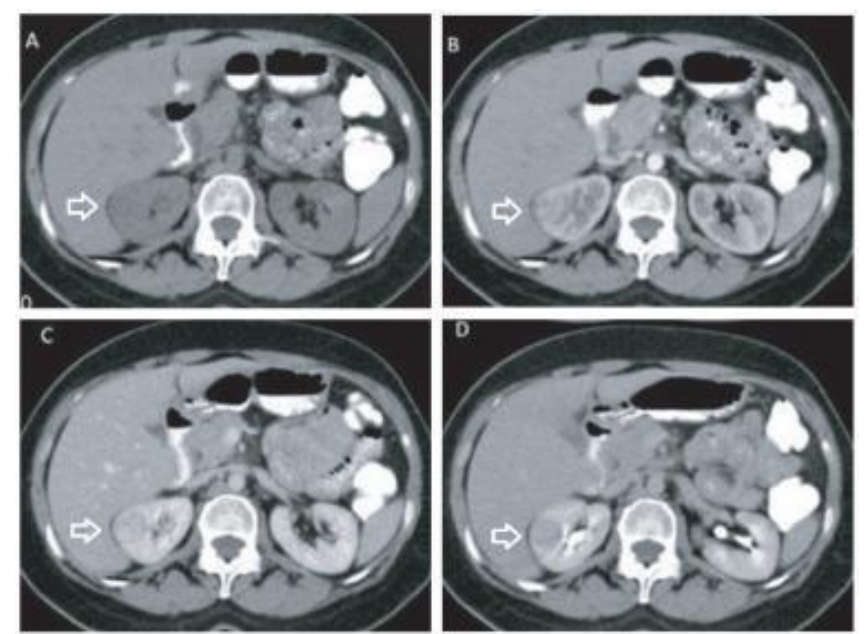

Figure 5. Incidence of kidney detected in US. (a) Unenhanced CT depicts a constricted renal mass (arrow) in the center of the right kidney. (b) An inhomogeneous pattern of enhancement (arrows) is seen in the corticomedullary phase. The lesion (arrow) has a subtle washout effect (c) in the nephrogenic 
phase, becoming more intense (d) in the excretory phase. Kidney tumor biopsy showed renal oncocytoma.

CECT is widely accepted as the diagnostic modality of choice for staging RCC, with a sensitivity and specificity of up to $90 \%[2,3,4,14,103,104]$. The size of the RCC and the degree of local invasion determined the T stage (Table 1). Although, several studies have reported that CT often overestimates tumor size, compared to surgical specimens, the differences are minimal and clinically insignificant in most cases [105, 106]. Fatty invasion of the perinephric sinus or kidney is not always easily detected on CT [107]. Thin sections and multiplanar reforms have improved the detection of perinephric fatty infiltration, despite false positives, because inflammation, edema, vascular swelling, or fibrosis may be encountered [107, 108, 109]. CT is highly accurate in diagnosing the spread of RCC into the renal vein, with an NPV of $97 \%$ and PPV of $92 \%[14,110]$. CT is also effective in assessing the degree of superior inferior vena cava thrombus [111].

CT offers a high NPV in excluding involvement of adjacent organs outside of Gerota's fascia or involvement of the ipsilateral adrenal glands [14, 112, 113]. In a retrospective observational study, CT had $100 \%$ sensitivity, $95.2 \%$ specificity and 100\% NPV in diagnosing adrenal gland invasion [113]. However, CT is not always able to distinguish abutments from direct invasion [14].

CT tends to overdiagnose lymph node spread, which is defined as lymph nodes with a short axis diameter greater than $1 \mathrm{~cm}$ and abnormal lymph node architecture. However, based on size criteria, CT has $10 \%$ false negatives, whereas approximately $50 \%$ of enlarged lymph nodes prove to be benign [14,114]. Distant metastases from RCC are frequently found in the lung, bone, liver, and brain and less frequently in the thyroid, pancreas, muscle, skin, and soft tissues [14, 115]. Chest CT is useful for detecting pulmonary and mediastinal lymph node metastases and is especially recommended in large RCCs [14]. Visceral metastases tend to be hypervascular and the corticomedullary phase can help detect arterial elevation $[14,115]$.

Multiplanar reform and three-dimensional reconstruction are helpful in preoperative planning, providing important anatomic information, such as the position of the kidney relative to surrounding bone, tumor location and depth of extension to the kidney, relationship of the tumor to the renal collecting system, and accurate depiction of the anatomy of arteries and veins [116]. , 117] Preoperative CT also provides information about the morphology and function of the contralateral kidney. Synchronous primary tumors should be sought, as RCC can be multifocal [14].

$\mathrm{CT}$ is indicated for follow-up of RCC after surgery or post-ablation, in patients at moderate to high risk [18]. Basic chest and abdominal CT within three to six months after surgery is recommended, followed by imaging every six months for at least three years and annually thereafter, for two years [118].

\section{Multiparametric MRI Multiparametric}

MRI is a valuable complementary imaging technique for the assessment of renal masses, providing morphological and functional information [5, 6, 7, 12, 13, 14, 18, 31, 32]. MRI is especially recommended when optimal CT cannot be performed (severe allergy to iodinated CT contrast or high risk for contrast-induced nephropathy) or when radiation exposure is contraindicated (young age or pregnant women) $[5,6,7,12,13,14,18,31,32]$. However, gadolinium-based MR agents should be administered with caution during pregnancy, only if there is a very strong clinical indication and the potential benefit justifies the potential unknown risk to the fetus [119]. When iodinated CT contrast and gadolinium-based MR agents cannot be used, MRI without iv contrast is highly recommended for renal mass characterization, RCC staging and follow-up (Fig. 6) [5, 6, 12, 13, 14, 18].

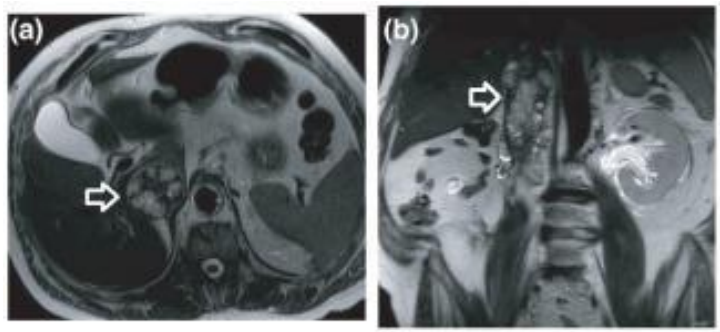

Figure 6. Unenhanced follow-up MRI in a patient with renal failure and a history of right radical nephrectomy, due to RCC. T2-weighted imaging in (a) axial and (b) coronal planes demonstrates a neoplastic thrombus (arrows) into the inferior vena cava. 
The renal MRI protocol includes the following sequence: T1-weighted with deep-phase and counter-phase imaging (or the DIXON technique), T2-weighted, diffusion-weighted (DWI) imaging, dynamic contrast-enhanced and delaying, T1 post- contrast-weighted imaging [120].

Although CT and MRI have similar accuracy in characterizing cystic renal masses, mpMRI may show additional findings, such as more septa, wall and/or septal thickening and contrast enhancement, which may result in lesion enhancement (Table 4) [5,6, 12,121 ] , 122, 123, 124]. MRI, because of its advantages over CT, namely decreased sensitivity to calcification, increased sensitivity to enhancement and the absence of pseudoenhancement, can provide additional diagnostic information in the assessment of renal cystic masses, with abundant thick or nodular calcifications on CT, hyperdense, homogeneous non-enlarging tumor renal, larger than $3 \mathrm{~cm}$ and heterogeneous, non-enhancing mass on CT $[12,13]$.

CT, MRI and CEUS represent equivalent alternatives for the initial assessment of an indeterminate renal mass [6]. MRI is especially recommended for the assessment of solid renal masses with inconclusive CT findings, especially those smaller than $1.5 \mathrm{~cm}[5,6,125,126]$.

Multiparametric MRI features, including T2 signal, chemical shift imaging characteristics, apparent diffusion coefficient (ADC) signal, early enhancement pattern and de-enhancement aid in the characterization of solid renal tumors (Table 5) [7,31, 32, 63,127, 128, 129 ]. Clear cell RCCs are often large and heterogeneous, with high T2 and ADC signals, and early, strong heterogeneous increases, followed by rapid decreases (Fig. 7) [7,31, 32, 63,127, 128, 129, 130, 131 , 132]. Tumor pseudocapsules are frequently detected as a low T2 signal halo around the neoplasm (Fig. 7b) and suggest renal disease [133]. Multiparametric MRI has a sensitivity and specificity of up to $92 \%$ and $83 \%$, respectively, in the diagnosis of clear cell RCC [32].
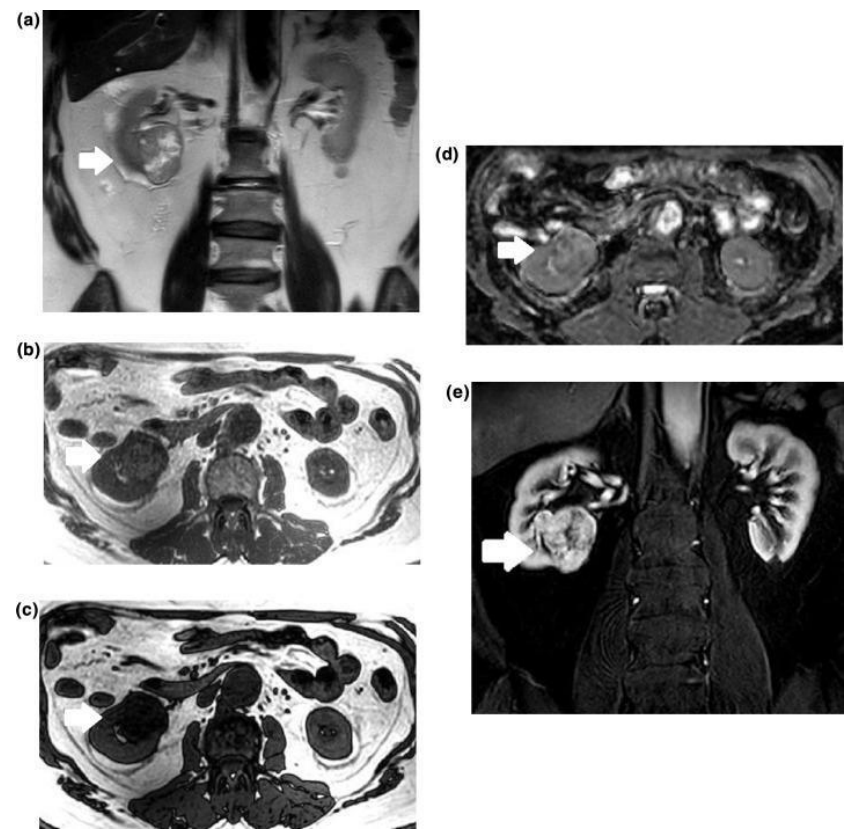

Figure 7. (a) Coronal T2-weighted image depicting a heterogeneous right lower polar renal mass (arrows), with a high T2 signal. A hyperintense central intratumoral area is seen, due to necrosis. The tumor is surrounded by a low T2 signal halo, corresponding to the pseudocapsule, in pathology. Axial images of (b) deep phase and (c) opposite phase T1 show decreased signal (arrow) on opposite imaging, due to the presence of intratumoral fat. (d) Axial ADC map ( $b=600 \mathrm{~s} / \mathrm{mm} 2$ ). The mass (arrow) has a signal similar to that of the surrounding renal parenchyma. (e) Coronal-reduced dynamic contrastenhanced image showing a strongly and heterogeneously enhanced tumor (arrow).

Papillary RCCs are often small, peripherally located, with low T2 and ADC signals and a slow, progressive increase. Intratumoral hemorrhage is frequently detected, either as a hyperintense T1 area or as a signal reduction on phase imaging, corresponding to prolonged or chronic bleeding $[31,32,68,134$, $135,136,137]$. A recently published retrospective study of 109 resected small renal tumors reported a diagnostic accuracy of $81 \%$ and $91 \%$ in the characterization of clear cell RCC and papillary RCC, using mpMRI, respectively, with moderate to substantial inter-reader agreement among seven radiologists [135]. Chromophobe RCC typically have a medium to low T2 signal, low ADC when compared to clear cell RCC, and, initially, an intermediate increase, followed by a gradual decrease [31, 32, 82, 134]. 
Multiparametric MRI often allows the characterization of lipid-poor AML, with a sensitivity and specificity of up to $100 \%$ and $89 \%$, respectively [31]. Fat-poor AML is characteristically small, homogeneously hypointense on T2-weighted imaging and ADC maps, with avid, baseline enhancement and rapid washout. Intratumoral fat is seldom detected, as the signal decreases on opposite-phase imaging [31,134,138]. Common mpMRI findings of renal oncocytoma include: peripheral location, moderately high T2 signal, high, strong ADC, early elevation and gradual decline [31,32, 139].

Results on the efficacy of DWI in the characterization of solid renal masses are conflicting, with significant ADC overlap among the different histologic subtypes. However, DWI can be used to predict the histologic grade of RCC, with limited diffusion often seen in high-grade clear cell RCC, when compared with low-grade tumors [140, 141, 142, 143, 144, 145].

A variety of new MRI techniques, including intravoxel incoherent motion, diffusion kurtosis, texture analysis, arterial loop labeling, MRI and radiomics dependent on blood oxygenation levels have been introduced for characterization of renal masses, evaluation of RCC aggressiveness, and assessment of treatment response, although validation is required [146 , 147, 148, 149, 150, 151]. In addition, investigation of the biochemical environment of the renal mass by additional proton MR spectroscopy can aid in lesion characterization [152].

CT and MRI represent equivalent alternatives for staging RCC, with similar diagnostic performance [14]. MRI can provide additional information in cases with uncertain CT findings, particularly when assessing perinephric fat infiltration, extension of a neoplastic thrombus into the renal vein and/or inferior vena cava, and possible invasion of the inferior vena cava wall by RCC thrombus $[14,153], 154]$.

Both CT and MRI perform well in postoperative or post-ablation RCC follow-up, with high accuracy in detecting local recurrence and/or distant metastases [18]. In low-risk RCC, MRI can be used as the main modality for follow-up, in the absence of radiation exposure [[2]]. When intravenous contrast is contraindicated, follow-up MRI without iv contrast is recommended (Fig. 5) [18]. CT, MRI and CEUS are usually recommended for active surveillance of local RCC [18].

\section{Minimally Invasive RCC Curative Management, image-guided}

Advanced RCC has a clear management pathway consisting primarily of radical nephrectomy or palliative treatment. Management of small, early-stage, asymptomatic, sporadic RCC is slightly more complex, given the unpredictable behavior of the lesions. The general consensus is to assess growth patterns with active surveillance. When treatment is considered, open or laparoscopic partial nephrectomy appears to be the standard approach, aiming to preserve as much of the healthy parenchyma as possible.

Interventional Oncology may offer another minimally invasive locoregional treatment for such patients with percutaneous image-guided ablation [19], [20, 155]. Percutaneous ablation is a form of treatment used in a number of other organs [156]. The technology initially applied for ablation of renal tumors was radiofrequency [157]. This approach is fueled by the need to treat patients who are poor surgical candidates or who have limited life expectancy for other reasons with effective minimally invasive procedures. Radiofrequency thermal effects are based on high-frequency electric currents which cause oscillations of tissue molecules and generate heat [158]. When the temperature exceeds $60^{\circ} \mathrm{C}$, the tissue is destroyed. This technology is now established in the treatment of small renal masses, with excellent long-term results $[159,160]$. Cryoablation is another established modality for the percutaneous image-guided treatment of RCC. The physical principle of cryoablation is based on the Joule-Thompson principle which describes the decrease in temperature after the rapid expansion of Argon. The lethal effect of cryoablation is based on direct cellular damage caused by osmotic cellular dehydration due to extracellular freezing and due to intracellular ice formation [161]. Percutaneous cryoablation also offers excellent long-term results in the management of small renal masses [162, 163]. Furthermore, microwave ablation was recently introduced in the treatment of percutaneous RCC and has yielded some encouraging results [164]. Microwave is based on the use of electromagnetic waves that cause continuous rotation of tissue water molecules. The uneven distribution of electric charge of water molecules causes continuous reorientation in the oscillating field; this movement increases its kinetic energy and is stored in the tissues as heat energy [164].

Minimally invasive percutaneous ablation has an important role in patients with multiple bilateral synchronous RCC, such as in von-Hippel-Lindau syndrome (VHL) [165]. Another group of patients who may benefit significantly from percutaneous ablation are patients who undergo nephrectomy and develop a new RCC or metastatic lesion in the contralateral kidney or those who develop an RCC in the single-functioning kidney [166]. For such patients, percutaneous ablation offers a valid tumor control solution, with preservation of renal function [166, 167, 168]. 
Although at least three ablation modalities are used for the locoregional treatment of percutaneous RCC, there is no evidence of the superiority of any of the three to date regarding complications, postprocedure renal function testing, local tumor progression, or cancer-specific survival $[169,170,171,172,173]$.

One of the main advantages of percutaneous ablation is that the level of sedation can be individually adjusted and can be performed safely under moderate sedation, monitored anesthesia, or if needed, general anesthesia. [20,174]]. The decision to proceed needs to be obtained through a multidisciplinary meeting. The interventional radiologist should consult with the patient prior to the procedure, to discuss the risks and benefits of the procedure, anesthetic options and to assess the patient's fitness. Anticoagulation should be discontinued, according to standard percutaneous procedures and in the case of Warfarin, bridging with heparin is necessary [175].

Imaging guidance can be performed with a variety of modalities including US, CT, MRI, PET, CT-fluoroscopy, or cone-beam CT. Decisions regarding imaging guidelines should take into account patient factors, availability, cost, radiation dose, and operator preferences. A navigation system has also been developed, which offers more accurate needle placement and can also predict the area of ablation [176] (Fig. 8). The patient will usually be admitted to the hospital on the day of the procedure, will be transferred to the post procedure ward for overnight observation and discharged the next morning, aiming for a stay of less than 24 hours in the hospital. While the patient is in the CT room, premedication with $1000 \mathrm{mg}$ of intravenous Paracetamol is given and then, conscious sedation is given with $1-4 \mathrm{mg}$ of Midazolam and 50-200 micrograms of Fentanyl, just prior to ablation [20, 174].
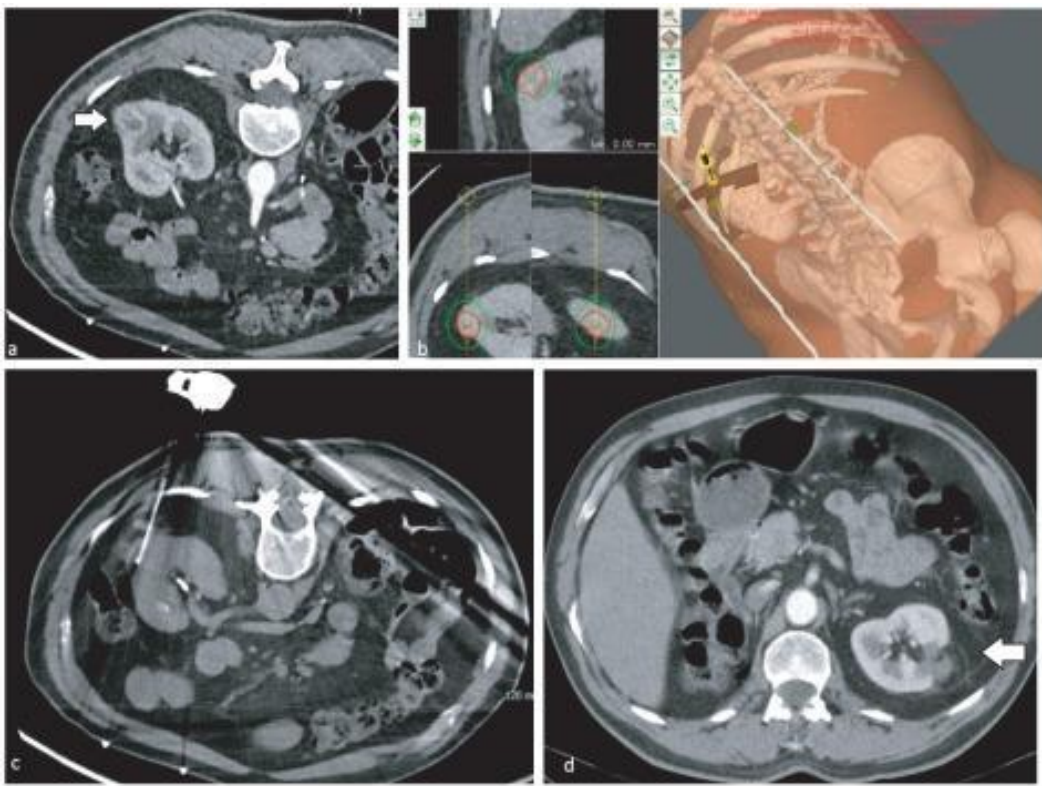

Figure 8. CT-guided percutaneous ablation of a small endophytic left renal tumor in a male previously diagnosed with clear cell RCC of the contralateral kidney, treated by radical nephrectomy. Five years later, he showed a new primary left kidney mass of $1.7 \mathrm{~cm}$. Kidney tumor biopsy confirmed clear cell RCC of the left kidney. After the Multidisciplinary Team Meeting, the decision to proceed with lesion ablation was made. (a) CT scan with axial contrast in the corticomedullary phase confirming the position of the small left renal endophytic lesion (arrow). (b) A CT-guided navigation system (CASOneÒIR, CASCINATION AG, Bern, Switzerland) was used to target the tumor and predict the area of ablation (green circle). Navigation is helpful in such cases, as the lesions are difficult to target, due to their small size and endophytic growth. (c) RFA electrodes are inserted, and ablation is performed for 12 minutes. (d) Follow-up contrast-enhanced CT in the corticomedullary phase six months later confirmed satisfactory ablation of the area, with lack of enhancement and the presence of a "halo" sign (arrow). Satisfactory results were also confirmed in five years of follow-up, with preservation of renal function.

A biopsy of the renal lesion should be performed, prior to ablation in all cases. Usually this is obtained before any discussion in the Multidisciplinary Team Meeting (MDT) for sporadic lesions. For patients with VHL or patients with known contralateral tumors, no biopsy is required prior to MDT discussion and the lesion is biopsied before ablation in the same session. In such cases, the biopsy should be performed via a coaxial system that will also be used as an access electrode, as post-biopsy bleeding may limit delineation of the lesion boundaries [177]. 
In cases of proximity to the bowel, hydro dissection with a non-ionic solution should be considered, via a thin needle, to replace the bowel and to isolate the lesion [178].

Follow-up with three-phase CT is required four weeks after ablation, to assess whether there is any residual enhancing tissue. In case of incomplete ablation of the lesion, a second session is required as soon as possible. If the results of ablation are satisfactory, with no lesion enhancement, then followup with three-phase CT at six and 12 months is required, and annually thereafter, for a total of five years $[179,180,181]$.

Ablation offers excellent long-term oncological outcomes in the treatment of locoregional RCC and should be offered to any patient with tumors up to $4 \mathrm{~cm}$ in diameter. More specifically, the reported primary efficacy for the treatment of T1a tumors ranged from 94.4-98.2\%, with secondary efficacy ranging from $98.5 \%-99.1 \%[159,162,182]$.

\section{Conclusion}

Renal masses are increasingly being detected in asymptomatic individuals, as an incidental finding on cross-sectional imaging. Multimodality imaging, including US, CEUS, CECT and mpMRI plays an important role in the detection and characterization of renal masses, staging of RCCs and followup of surgically treated or untreated RCCs. Conventional US often represents the first-line imaging tool for the assessment of renal pathology. This technique can accurately characterize simple renal cysts and minimally complex cysts. CEUS has emerged as a powerful adjunct tool for the characterization of renal masses. Well-established applications of CEUS include differentiation between solid and pseudotumor renal tumors, characterization of complex cysts and indeterminate renal lesions and follow-up of renal masses not treated surgically. CT is the examination of choice for assessment of an indeterminate renal mass, RCC staging and follow-up, in moderate and high risk patients. Multiparametric MRI is a useful adjunct in the management of renal masses, particularly when indicated when optimal CT cannot be performed (history of allergy or renal insufficiency) or when ionizing radiation is contraindicated (young age or pregnancy). This technique can provide additional useful information in the characterization of solid and cystic renal tumors, particularly small renal masses. MRI is also recommended for follow-up of low-risk RCC.

Percutaneous image-guided ablation is an effective therapy for localized RCC, with acceptable outcomes. Main indications include management of small renal masses $(\leq 4 \mathrm{~cm})$, multiple RCCs (eg, in VHL syndrome) and RCCs in solitary kidneys.

A structured template, including a nephrometric score and associated additional CT or MRI findings for reporting solid renal masses, greatly assists clinicians in planning appropriate treatment.

\section{REFERENCES}

1] M. Jayson, H. Sanders, Increased incidence of serendipitously discovered renal cell carcinoma, Urology 51 (1998) 203-205, https://doi.org/10.1016/s0090- 4295(97)00506-2.

2] B. Ljungberg, L. Albiges, Y. Abu-Ghanem, K. Bensalah, S. Dabestani, S. Fernandez-Pello,' RH Giles, F. Hofmann, M. Hora, MA Kuczyk, T. Kuusk, TB Lam, L. Marconi, AS Merseburger, T. Powles, M. Staehler, R. Tahbaz, A. Volpe, A. Bex, European association of urology guidelines on renal cell carcinoma: the 2019 update, Eur. Urol. 75 (2019) 799 810, https://doi.org/ 10.1016/j.eururo.2019.02.011.

3] S. Campbell, RG Uzzo, ME Allaf, EM Remer, Renal Mass and Localized Renal Cancer: AUA Guideline, J. Urol. 198 (2017) 520-529, https://doi.org/10.1016/j. juro.2017.04.100.

4] RD Ward, H. Tanaka, SC Campbell, EM Remer, 2017 AUA renal mass and localized renal Cancer guidelines: imaging implications, Radiographics 38 (2018) 2021-2033, https://doi.org/10.1148/rg.2018180127.

5] BR Herts, SG Silverman, NM Hindman, RG Uzzo, RP Hartman, GM Israel, DA Baumgarten, LL Berland, PV Pandharipande, Management of the Incidental Renal Mass on CT: A White Paper of the ACR Incidental Findings Committee, J. Am. Coll. Radiol. 15 (2018) 264-273, https://doi.org/10.1016/j. jacr.2017.04.028.

6] Expert Panel on Urologic Imaging, ZJ Wang, P. Nikolaidis, G. Khatri, VS Dogra, D. Ganeshan, S. Goldfarb, JL Gore, RT Gupta, RP Hartman, ME Heilbrun, A. Lyshchik, AS Purysko, SJ Savage, AD Smith, DJ Wolfman, JJ Wong-YouCheong, ME Lockhart, ACR appropriateness criteria ${ }^{\circledR}$ indeterminate renal mass, J. Am. Coll. Radiol. 17 (2020) S415S428, https://doi.org/10.1016/j. jacr.2020.09.010. 
7] FU Kay, I. Pedrosa, Imaging of solid renal masses, Urol. Clin. North Am. 45 (2018) 311330, https://doi.org/10.1016/j.ucl.2018.03.013.

8] E. Guðmundsson, H. Hellborg, S. Lundstam, S. Erikson, B. Ljungberg, Metastatic potential in renal cell carcinomas $\leq 7 \mathrm{~cm}$ : swedish kidney Cancer quality register data, Eur. Urol. 60 (2011) 975-982, https://doi.org/10.1016/j. eururo.2011.06.029.

9] A. Volpe, T. Panzarella, RA Rendon, MA Haider, FI Kondylis, MAS Jewett, The natural history of incidentally detected small renal masses, Cancer 100 (2004) 738-745, https://doi.org/10.1002/cncr.20025.

10] KH Tsui, O. Shvarts, RB Smith, R. Figlin, JB de Kernion, A. Belldegrun, Renal cell carcinoma: prognostic significance of incidentally detected tumors, J. Urol. 163 (2000) 426430, https://doi.org/10.1016/s0022-5347(05)67892-5.

11] JJ Patard, A. Rodriguez, N. Rioux-Leclercq, F. Guille, B. Lobel, Prognostic significance of the mode of detection in renal tumours, BJU Int. 90 (2002) 358-363, https://doi.org/10.1046/j.1464-410x.2002.02910.x.

12] SG Silverman, I. Pedrosa, JH Ellis, NM Hindman, N. Schieda, AD Smith, EM Remer, AB Shinagare, NE Curci, SS Raman, SA Wells, SD Kaffenberger, ZJ Wang, H. Chandarana, MS Davenport, Bosniak classification of cystic renal masses, version 2019: an update proposal and needs assessment, Radiology 292 (2019) 475-488, https://doi.org/10.1148/radiol.2019182646.

13] S. Krishna, N. Schieda, I. Pedrosa, N. Hindman, RH Baroni, SG Silverman, MS Davenport, Update on MRI of cystic renal masses including bosniak version 2019, J. Magn. Reson. Imaging 2 (2020), https://doi.org/10.1002/jmri.27364

14] R. Vikram, MD Beland, MD Blaufox, CC Moreno, JL Gore, HJ Harvin, ME Heilbrun, SL Liauw, PL Nguyen, P. Nikolaidis, GM Preminger, AS Purysko, SS Raman, MT Taffel, ZJ Wang, RM Weinfeld, EM Remer, ME Lockhart, ACR appropriateness criteria renal cell carcinoma staging, J. Am. Coll. Radiol. 13 (2016) 518-525, https://doi.org/10.1016/j.jacr.2016.01.021.

15] American Joint Committee on Cancer Kidney, MB Amin, S. Edge, F. Greene, et al. (Eds.), AJCC Cancer Staging Manual, 8th ed, Springer-Verlag, New York, NY, 2017, pp. 747-756.

16] H. Moch, AL Cubilla, PA Humphrey, VE Reuter, TM Ulbright, The 2016 WHO classification of tumours of the urinary system and male genital organs-part a: renal, penile, and testicular tumours, Eur. Urol. 70 (2016) 93-105, https://doi. org/10.1016/j.eururo.2016.02.029.

17] B. Delahunt, JC Cheville, G. Martignoni, PA Humphrey, C. Magi-Galluzzi, J. McKenney, L. Egevad, F. Algaba, H. Moch, DJ Grignon, R. Montironi, JR Srigley, Members of the ISUP Renal Tumor Panel, the International Society of Urological Pathology (ISUP) grading system for renal cell carcinoma and other prognostic parameters, Am. J. Surg. Pathol. 37 (2013) 1490-1504, https://doi. org/10.1097/PAS.0b013e318299f0fb.

18] Expert Panel on Urological Imaging, AS Purysko, P. Nikolaidis, VS Dogra, D. Ganeshan, JL Gore, RT Gupta, ME Heilbrun, G. Khatri, AU Kishan, A. Lyshchik, SJ Savage, AD Smith, ZJ Wang, DJ Wolfman, JJ Wong-YouCheong, DC Yoo, ME Lockhart, ACR appropriateness criteria post-treatment follow-up and active surveillance of clinically localized renal cell Cancer, J. Am. Coll. Radiol. 16 (2019) S399-S416, https://doi.org/10.1016/j.jacr.2019.05.022.

19] K. Katsanos, L. Mailli, M. Krokidis, A. McGrath, T. Sabharwal, A. Adam, Systematic review and meta-analysis of thermal ablation versus surgical nephrectomy for small renal tumours, Cardiovasc. Intervent. Radiol. 37 (2014) 427-437, https://doi.org/10.1007/s00270014-0846-9.

20] ME Krokidis, F. Orsi, K. Katsanos, T. Helmberger, A. Adam, CIRSE guidelines on percutaneous ablation of small renal cell carcinoma, Cardiovasc. Intervent. Radiol. 40 (2017) 177-191, https://doi.org/10.1007/s00270-016-1531-y.

21] M. Borghesi, E. Brunocilla, A. Volpe, H. Dababneh, CV Pultrone, V. Vagnoni, G. La Manna, A. Porreca, G. Martorana, R. Schiavina, Active surveillance for clinically localized renal tumors: An updated review of current indications and clinical outcomes, Int. J. Urol. 22 (2015) 432-438, https://doi.org/10.1111/iju.12734.

22] M. Nayyar, P. Cheng, B. Desai, S. Cen, M. Desai, I. Gill, V. Duddalwar, Active surveillance of small renal masses: a review on the role of imaging with a focus on growth rate, $\mathrm{J}$. Comput. Assist. Tomogr. 40 (2016) 517-523, https://doi.org/ 10.1097/RCT.0000000000000407. 
23] B. Musaddaq, T. Musaddaq, A. Gupta, S. Ilyas, C. von Stempel, Renal cell carcinoma: the evolving role of imaging in the 21st century, Semin. Ultrasound CT MR 41 (2020) 344-350, https://doi.org/10.1053/j.sult.2020.05.002.

24] R. Kaur, M. Juneja, AK Mandal, An overview of non-invasive imaging modalities for diagnosis of solid and cystic renal lesions, Med. Biol. Eng. Comput. 58 (2020) 1-24, https://doi.org/10.1007/s11517-019-02049-z.

25] P. Pavlica, L. Derchi, G. Martorana, E. Brunocilla, A. Bertaccini, F. Manferrari, A. Franceschelli, L. Barozzi, Renal cell carcinoma imaging, Eur. Urol. Sup. 5 (2006) 580-592, https://doi.org/10.1016/j.eursup.2006.03.010.

26] M. Bertolotto, S. Bucci, M. Valentino, F. Curro, ' C. Sachs, MA Cova, Contrastenhanced ultrasound for characterizing renal masses, Eur. J. Radiol. 105 (2018) 41-48, https://doi.org/10.1016/j.ejrad.2018.05.015.

27] M. Siddaiah, S. Krishna, MDF McInnes, JS Quon, WM Shabana, D. Papadatos, N. Schieda, Is Ultrasound Useful for Further Evaluation of Homogeneously Hyperattenuating Renal Lesions Detected on CT? AJR Am. J. Roentgenol. 209 (2017) 604-610, https://doi.org/10.2214/AJR.17.17814.

28] CM Burgan, R. Rupan Sanyal, ME Lockhart, Ultrasound of renal masses, Radiol. Clin. North Am. 57 (2019) 585-600, https://doi.org/10.1016/j.rcl.2019.01.009.

29] PS Sidhu, V. Cantisani, CF Dietrich, OH Gilja, A. Saftoiu, E. Bartels, M. Bertolotto, F. Calliada, D. Clevert, D. Cosgrove, A. Deganello, M. D'Onofrio, FM Drudi, S. Freeman, C. Harvey, C. Jenssen, E. Jung, AS Klauser, N. Lassau, MF Meloni, E. Leen, C. Nicolau, C. Nolsoe, F. Piscaglia, F. Prada, H. Prosch, M. Radzina, L. Savelli, H. Weskott, H. Wijkstra, The EFSUMB Guidelines and Recommendations for the Clinical Practice of ContrastEnhanced Ultrasound (CEUS) in Non-Hepatic Applications: Update 2017 (Long Version), Ultraschall Med. 39 (2018) e2-e44, https://doi.org/10.1055/s-0044-101254.

30] TJ van Oostenbrugge, JJ Fütterer, PFA Mulders, Diagnostic imaging for solid renal tumors: a pictorial review, Kidney Cancer 2 (2018) 79-93, https://doi.org/ 10.3233/KCA-180028.

31] C. Lopes Vendrami, CP Villavicencio, TJ DeJulio, A. Chatterjee, DD Casalino, JM Horowitz, DT Oberlin, G. Yang, P. Nikolaidis, FH Miller, Differentiation of solid renal tumors with Multiparametric MR imaging, Radiographics 37 (2017) 2026-2042, https://doi.org/10.1148/rg.2017170039.

32] F. Cornelis, N. Grenier, Multiparametric magnetic resonance imaging of solid renal tumors: a practical algorithm, Semin. Ultrasound CT MR 38 (2017) 47-58, https://doi.org/10.1053/j.sult.2016.08.009.

33] L. Marconi, S. Dabestani, TB Lam, F. Hofmann, F. Stewart, J. Norrie, A. Bex, K. Bensalah, SE Canfield, M. Hora, MA Kuczyk, AS Merseburger, PFA Mulders, T. Powles, M. Staehler, B. Ljungberg, A. Volpe, Systematic review and meta-analysis of diagnostic accuracy of percutaneous renal tumour biopsy, Eur. Urol. 69 (2016) 660-673, https://doi.org/10.1016/j.eururo.2015.07.072.

$34]$ N. Shi, F. Zu, Y. Shan, S. Chen, B. Xu, M. Du, M. Chen, The value of renal score in both determining surgical strategies and predicting complications for renal cell carcinoma: a systematic review and meta-analysis, Cancer Med. 9 (2020) 3944-3953, https://doi.org/10.1002/cam4.2993.

35] SM Lee, I. Robertson, T. Stonier, N. Simson, T. Amer, OM Aboumarzouk, Contemporary outcomes and prediction of adherent perinephric fat at partial nephrectomy: a systematic $\begin{array}{lllllll}\text { review, Scand. } & \text { J. } & \text { Urol. } & 51 & \text { (2017) } & 429-434, & \text { https:// }\end{array}$ doi.org/10.1080/21681805.2017.1357656.

36] N. Alsaikhan, W. Alshehri, F. Cassidy, L. Aganovic, N. Vahdat, Renal tumor structured reporting including nephrometry score and beyond: what the urologist and interventional radiologist need to know, Abdom. Radiol. (NY) 44 (2019) 190-200, https://doi.org/10.1007/s00261-018-1691-0.

37] A. Nilsson, Contrast-enhanced ultrasound of the kidneys, Eur. Radiol. 14 (2004) P104-109.

38] JM Correas, M. Claudon, F. Tranquart, O. H'el'enon, The kidney: imaging with microbubble contrast agents, Ultrasound Q. 22 (2006) 53-66.

39] CJ Harvey, A. Alsafi, S. Kuzmich, A. Ngo, I. Papadopoulou, A. Lakhani, Y. Berkowitz, S. Moser, PS Sidhu, DO Cosgrove, Role of US contrast agents in the assessment of indeterminate solid and cystic lesions in native and transplant kidneys, Radiographics 35 (2015) 1419-1430, https://doi.org/10.1148/ rg.2015140222.

40] A. Ignee, B. Straub, G. Schuessler, CF Dietrich, Contrast enhanced ultrasound of renal masses, World J. Radiol. 28 (2010) 15-31, https://doi.org/10.3233/CH2010-1352. 
41] DD Cokkinos, EG Antypa, M. Skilakaki, D. Kriketou, E. Tavernaraki, PN Piperopoulos, Contrast Enhanced Ultrasound of the Kidneys: What Is It Capable of? Biomed. Res. Int. (2013) 595873, https://doi.org/10.1155/2013/ 595873.

42] S. Mazziotti, F. Zimbaro, A. Pandolfo, S. Racchiusa, N. Settineri, G. Ascenti, Usefulness of contrast-enhanced ultrasonography in the diagnosis of renal pseudotumors, Abdom. Imaging 35 (2010) 241-245, https://doi.org/10.1007/ s00261-008-9499-y.

43] TH Oh, YH Lee, IY Seo, Diagnostic efficacy of contrast-enhanced ultrasound for small renal masses, Korean J. Urol. 55 (2014) 587-592, https://doi.org/ 10.4111/kju.2014.55.9.587.

44] ZF Xu, HX Xu, XY Xie, GJ Liu, YL Zheng, MD Lu, Renal cell carcinoma and renal angiomyolipoma: differential diagnosis with real-time contrast-enhanced ultrasonography, J. Ultrasound Med. 29 (2010) 709-717, https://doi.org/ 10.7863/jum.2010.29.5.709.

45] ZF Xu, HX Xu, XY Xie, GJ Liu, YL Zheng, JY Liang, MD Lu, Renal cell carcinoma: realtime contrast-enhanced ultrasound findings, Abdom. Imaging 35 (2010) 750-756, https://doi.org/10.1007/s00261-009-9583-y.

46] M. Atri, L. Tabatabaeifar, HJ Jang, A. Finelli, H. Moshonov, M. Jewett, Accuracy of contrast-enhanced US for differentiating benign from malignant solid small renal masses, Radiology 276 (2015) 900-908, https://doi.org/10.1148/ radiol.2015140907.

47] DA Clevert, N. Minaifar, S. Weckbach, EM Jung, K. Stock, M. Reiser, M. Staehler, Multislice computed tomography versus contrast-enhanced ultrasound in evaluation of complex cystic renal masses using the Bosniak classification system, Clin. Hemorheol. Microcirc. 39 (2008) 171-178.

48] BK Park, B. Kim, SH Kim, K. Ko, HM Lee, HY Choi, Assessment of cystic renal masses based on Bosniak classification: comparison of CT and contrast-enhanced US, Eur. J. Radiol. 61 (2007) 310-314, https://doi.org/10.1016/j. ejrad.2006.10.004.

49] G. Ascenti, S. Mazziotti, G. Zimbaro, N. Settineri, C. Magno, D. Melloni, R. Caruso, E. Scribano, Complex cystic renal masses: characterization with contrastenhanced US, Radiology 243 (2007) 158-165, https://doi.org/10.1148/ radiol.2431051924.

50] E. Quaia, M. Bertolotto, V. Cioffi, A. Rossi, E. Baratella, R. Pizzolato, MA Cova, Comparison of contrast-enhanced sonography with unenhanced sonography and contrastenhanced CT in the diagnosis of malignancy in complex cystic renal masses, AJR Am. J. Roentgenol. 191 (2008) 1239-1249, https://doi.org/ 10.2214/AJR.07.3546.

51] O. Graumann, SS Osther, J. Karstoft, A. Horlyck, PJ Osther, Bosniak classification system: a prospective comparison of CT, contrast-enhanced US, and MR for categorizing complex renal cystic masses, Acta Radiol. 57 (2016) 1409-1417, https://doi.org/10.1177/0284185115588124.

52] EH Chang, WK Chong, SK Kasoji, JR Fielding, E. Altun, LB Mullin, JI Kim, JP Fine, PA Dayton, WK Rathmell, Diagnostic accuracy of contrast-enhanced ultrasound for characterization of kidney lesions in patients with and without chronic kidney disease, BMC Nephrol. 18 (2017) 266, https://doi.org/10.1186/ s12882-017-0681-8.

53] M. Gulati, KG King, IS Gill, V. Pham, E. Grant, VA Duddalwar, Contrastenhanced ultrasound (CEUS) of cystic and solid renal lesions: a review, Abdom. Imaging 40 (2015) 1982-1996, https://doi.org/10.1007/s00261-015-0348-5.

54] M. Bertolotto, C. Cicero, R. Perrone, F. Degrassi, F. Cacciato, MA Cova, Renal masses with equivocal enhancement at CT: characterization with contrastenhanced ultrasound, AJR Am. J. Roentgenol. 204 (2015) W557-W565, https:// doi.org/10.2214/AJR.14.13375.

55] RG Barr, C. Peterson, A. Hindi, Evaluation of indeterminate renal masses with contrastenhanced US: a diagnostic performance study, Radiology 271 (2013) 133-142, https://doi.org/10.1148/radiol.13130161.

56] CJ Harvey, A. Alsafi, S. Kuzmich, A. Ngo, I. Papadopoulou, A. Lakhani, Y. Berkowitz, S. Moser, PS Sidhu, DO Cosgrove, Role of US contrast agents in the assessment of indeterminate solid and cystic lesions in native and transplant kidneys, Radiographics 35 (2015) 1419-1430, https://doi.org/10.1148/ rg.2015140222. AC Tsili et al. European Journal of Radiology 141 (2021) 10977712

57] Q. Li, Z. Wang, X. Ma, J. Tang, Y. Luo, Diagnostic accuracy of contrast-enhanced ultrasound for detecting bland thrombus from inferior vena cava tumor thrombus in patients with renal cell carcinoma, Int. Braz. J. Urol. 46 (2020) 92-100, https://doi.org/10.1590/S1677-5538.IBJU.2019.0304.

58] MF Meloni, M. Bertolotto, C. Alberzoni, S. Lazzaroni, C. Filice, T. Livraghi, G. Ferraioli, Follow-up after percutaneous radiofrequency ablation of renal cell carcinoma: contrast- 
enhanced sonography versus contrast-enhanced CT or MRI, AJR Am. J. Roentgenol. 191 (2008) 1233-1238, https://doi.org/10.2214/ AJR.07.3238.

59] SC Tenant, CM Gutteridge, The clinical use of contrast-enhanced ultrasound in the kidney, Ultrasound 24 (2016) 94-103, https://doi.org/10.1177/ 1742271X15627185.

60] ML Schnitzer, L. Sabel, V. Schwarze, C. Marschner, MF Froelich, P. Nuhn, Y. Falck, MM Nuhn, S. Afat, M. Staehler, J. Rückel, D.-A. Clevert, J. Rübenthaler, T. Geyer, Structured reporting in the characterization of renal cysts by contrastenhanced ultrasound (CEUS) using the bosniak classification systemimprovement of report quality and interdisciplinary $\begin{array}{lllll}\text { communication, } & \text { Diagnostics } & \text { (Basel) } & 11 & \text { (2021) }\end{array}$ https://doi.org/10.3390/diagnostics11020313.

61] V. Schwarze, J. Rübenthaler, C. Marschner, MP Fabritius, J. Rueckel, N. Fink, D. PuhrWesterheide, E. Gresser, MF Froelich, ML Schnitzer, N. Große Hokamp, S. Afat, M. Staehler, T. Geyer, D.-A. Clevert, Advanced fusion imaging and contrast-enhanced imaging (CT/MRI-CEUS) in oncology, Cancers $12 \quad$ (2020) 2821, https://doi.org/10.3390/cancers12102821.

62] P. Frinking, T. Segers, Y. Luan, FC Tranquart, Three decades of ultrasound contrast agents: a review of the past, present and future improvements, Ultrasound Med. Biol. 46 (2020) 892-908, https://doi.org/10.1016/j. ultrasmedbio.2019.12.008.

63] K. Sasaguri, N. Takahashi, CT and MR imaging for solid renal mass characterization, Eur. J. Radiol. 99 (2018) 40-54, https://doi.org/10.1016/j. ejrad.2017.12.008.

64] ZJ Wang, AC Westphalen, RJ Zagoria, CT and MRI of small renal masses, Br. J. Radiol. 91 (2018) 20180131, https://doi.org/10.1259/bjr.20180131.

65] S. Krishna, CA Murray, MD McInnes, R. Chatelain, M. Siddaiah, O. Al-Dandan, S. Narayanasamy, N. Schieda, CT imaging of solid renal masses: pitfalls and solutions, Clin. Radiol. 72 (2017) 708-721, https://doi.org/10.1016/j. crad.2017.05.003.

66] ZJ Wang, MS Davenport, SG Silverman, H. Chandarana, A. Doshi, GM Israel, JR Leyendecker, I. Pedrosa, S. Raman, EM Remer, AB Shinagare, AD Smith, R. Vikram, CT Renal Mass Protocol v1.0: Society of Abdominal Radiology Disease Focused Panel on Renal Cell Carcinoma, 2020 https://doi.org/ abdominalradiology.org/wpcontent/uploads/2020/11/RCC.CTprotocolsfinal-7- 15-17.pdf.

67] BA Birnbaum, JE Jacobs, P. Ramchandani, Multiphasic renal CT: comparison of renal mass enhancement during the corticomedullary and nephrographic phases, Radiology 200 (1996) 753-758, https://doi.org/10.1148/ radiology.200.3.8756927.

68] ND Egbert, EM Caoili, RH Cohan, MS Davenport, IR Francis, LP Kunju, JH Ellis, Differentiation of papillary renal cell carcinoma subtypes on CT and MRI, AJR Am. J. Roentgenol. 201 (2013) 347-355, https://doi.org/10.2214/ AJR.12.9451.

69] RD Ward, EM Remer, Cystic renal masses: an imaging update, Eur. J. Radiol. 99 (2017) 103-110, https://doi.org/10.1016/j.ejrad.2017.12.015.

70] S. Narayanasamy, S. Krishna, AK Prasad Shanbhogue, TA Flood, N. Sadoughi, P. Sathiadoss, N. Schieda, Contemporary update on imaging of cystic renal masses with histopathological correlation and emphasis on patient management, Clin. Radiol. 74 (2019) 83-94, https://doi.org/10.1016/j.crad.2018.09.003.

71] N. Schieda, MS Davenport, S. Krishna, EA Edney, I. Pedrosa, N. Hindman, RH Baroni, NE Curci, A. Shinagare, SG Silverman, Bosniak classification of cystic renal masses, version 2019: a pictorial guide to clinical use, Radiographics 16 (2021) 200160, https://doi.org/10.1148/rg.2021200160.

72] E. Edney, MS Davenport, N. Curci, N. Schieda, S. Krishna, N. Hindman, SG Silverman, I. Pedrosa, Bosniak classification of cystic renal masses, version 2019: interpretation pitfalls and recommendations to avoid misclassification, Abdom. Radiol. (NY) 23 (2021), https://doi.org/10.1007/s00261-020-02906-8.

73] BA Birnbaum, N. Hindman, J. Lee, JS Babb, Renal cyst pseudoenhancement: influence of multidetector CT reconstruction algorithm and scanner type in phantom model, Radiology 244 (2007) 767-775, https://doi.org/10.1148/ radiol.2443061537.

74] JH Kim, HY Sun, J. Hwang, SS Hong, YJ Cho, SW Doo, WJ Yang, YS Song, Diagnostic accuracy of contrast-enhanced computed tomography and contrast-enhanced magnetic resonance imaging of small renal masses in real practice: sensitivity and specificity according to subjective radiologic interpretation, World J. Surg. Oncol. 12 (2016) 260, https://doi.org/10.1186/ s12957-016-1017-z.

75] T. Kwon, IG Jeong, S. Yoo, SJ Lee, S. Hong, D. You, JH Hong, H. Ahn, C. Kim, Role of MRI in indeterminate renal mass: diagnostic accuracy and impact on clinical decision 
making, Int. Urol. Nephrol. 47 (2015) 585-593, https://doi.org/ 10.1007/s11255-015-0928$\mathrm{x}$.

76] J. Patel, MS Davenport, S. Khalatbari, RH Cohan, JH Ellis, JF Platt, In vivo predictors of renal cyst pseudoenhancement at $120 \mathrm{kVp}$, AJR Am. J. Roentgenol. 202 (2014) 336-342, https://doi.org/10.2214/AJR.13.10915.

77] NS Patel, L. Poder, ZJ Wang, BM Yeh, A. Qayyum, H. Jin, FV Coakley, The characterization of small hypoattenuating renal masses on contrast-enhanced CT, Clin. Imaging 33 (2009) 295-300, https://doi.org/10.1016/j. clinimag.2008.12.002.

78] GM Israel, MA Bosniak, Pitfalls in renal mass evaluation and how to avoid them, Radiographics 28 (2008) 1325-1338, https://doi.org/10.1148/ rg.285075744.

79] KZ Sheir, M. El-Azab, A. Mosbah, M. El-Baz, AA Shaaban, Differentiation of renal cell carcinoma subtypes by multislice computerized tomography, J. Urol. 174 (2005) 451-455, https://doi.org/10.1097/01.ju.0000165341.08396.a9.

80] JR Young, D. Margolis, S. Sauk, AJ Pantuck, J. Sayre, SS Raman, Clear cell renal cell carcinoma: discrimination from other renal cell carcinoma subtypes and oncocytoma at multiphasic multidetector CT, Radiology 267 (2013) 444-453, https://doi.org/10.1148/radiol.13112617.

81] JK Kim, SY Park, JH Shon, KS Cho, Angiomyolipoma with minimal fat: differentiation from renal cell carcinoma at biphasic helical CT, Radiology 230 (2004) 677-684, https://doi.org/10.1148/radiol.2303030003.

82] AB Rosenkrantz, N. Hindman, EF Fitzgerald, BE Niver, J. Melamed, JS Babb, MRI features of renal oncocytoma and chromophobe renal cell carcinoma, AJR Am. J. Roentgenol. 195 (2010) W421-W427, https://doi.org/10.2214/ AJR.10.4718.

83] S. Choudhary, A. Rajesh, NJ Mayer, KA Mulcahy, A. Haroon, Renal oncocytoma: CT features cannot reliably distinguish oncocytoma from other renal neoplasms, Clin. Radiol. 64 (2009) 517-522, https://doi.org/10.1016/j. crad.2008.12.011.

84] G. Gakis, U. Kramer, D. Schilling, S. Kruck, A. Stenzl, HP Schlemmer, Small renal oncocytomas: differentiation with multiphase CT, Eur. J. Radiol. 80 (2011) 274-278, https://doi.org/10.1016/j.ejrad.2010.06.049.

85] D. Giambelluca, S. Pellegrino, M. Midiri, G. Salvaggio, The "central stellate scar" sign in renal oncocytoma, Abdom. Radiol. (NY) 44 (2019) 1942-1943, https:// doi.org/10.1007/s00261-019-01899-3.

86] JI Kim, JY Cho, KC Moon, HJ Lee, SH Kim, Segmental enhancement inversion at biphasic multidetector CT: characteristic finding of small renal oncocytoma, Radiol 252 (2009) 441448, https://doi.org/10.1148/ radiol.2522081180.

87] N. Schieda, M. Al-Subhi, TA Flood, M. El-Khodary, MDF McInnes, Diagnostic accuracy of segmental enhancement inversion for the diagnosis of renal oncocytoma using biphasic computed tomography (CT) and multiphase contrastenhanced magnetic resonance imaging (MRI), Eur. Radiol. 24 (2014) 2787-2794, https://doi.org/10.1007/s00330-014-3310-y.

88] CG Moldovanu, B. Petresc, A. Lebovici, A. Tamas-Szora, M. Suciu, N. Crisan, P. Medan, MM Buruian, Differentiation of clear cell renal cell carcinoma from other renal cell carcinoma subtypes and benign oncocytoma using quantitative MDCT enhancement parameters, Medicina (Kaunas) 28 (2020) 569, https://doi. org/10.3390/medicina56110569.

89] BK Park, Renal Angiomyolipoma: Radiologic Classification and Imaging Features According to the Amount of Fat, AJR Am. J. Roentgenol. 209 (2017) 826-835, https://doi.org/10.2214/AJR.17.17973.

90] N. Takahashi, S. Leng, K. Kitajima, D. Gomez-Cardona, P. Thapa, RE Carter, BC Leibovich, K. Sasiwimonphan, K. Sasaguri, A. Kawashima, Small $(<4 \mathrm{~cm})$ renal masses: differentiation of angiomyolipoma without visible fat from renal cell carcinoma using unenhanced and contrast-enhanced CT, AJR Am. J. Roentgenol. 205 (2015) 1194-1202, https://doi.org/10.2214/AJR.14.14183.

91] SG Silverman, GM Israel, QD Trinh, Incompletely characterized incidental renal masses: emerging data support conservative management, Radiology 275 (2015) 28-42, https://doi.org/10.1148/radiol.14141144.

92] J. Salameh, MDF McInnes, TA McGrath, G. Salameh, N. Schieda, Diagnostic accuracy of dual-energy CT for evaluation of renal masses: systematic review and meta-analysis, AJR Am. J. Roentgenol. 212 (2019) W100-W105, https://doi.org/ 10.2214/AJR.18.20527.

93] D. Marin, D. Davis, KR Choudhury, B. Patel, RT Gupta, A. Mileto, RC Nelson, Characterization of small focal renal lesions: diagnostic accuracy with singlephase contrastenhanced dual-energy CT with material attenuation analysis compared with conventional 
attenuation measurements, Radiology $284 \quad$ (2017) 737-747, https://doi.org/10.1148/radiol.2017161872.

94] FG Mazzei, MA Mazzei, NC Squitieri, C. Pozzessere, L. Righi, A. Cirigliano, S. Guerrini, D. D'Elia, MR Ambrosio, A. Barone, MT del Vecchio, L. Volterrani, CT perfusion in the characterization of renal lesions: an added value to multiphasic CT, Biomed Res. Int. 2014 (2014), 135013, https://doi.org/10.1155/ 2014/135013.

95] Z. Feng, Q. Shen, Y. Li, Z. Hu, CT texture analysis: a potential tool for predicting the Fuhrman grade of clear-cell renal carcinoma, Cancer Imaging 19 (2019) 6, https://doi.org/10.1186/s40644-019-0195-7.

96] Y. Deng, E. Soule, A. Samuel, S. Shah, E. Cui, M. Asare-Sawiri, C. Sundaram, C. Lall, K. Sandrasegaran, CT texture analysis in the differentiation of major renal cell carcinoma subtypes and correlation with Fuhrman grade, Eur. Radiol. 29 (2019) 6922-6929, https://doi.org/10.1007/s00330-019-06260-2.

97] J. Shu, Y. Tang, J. Cui, R. Yang, X. Meng, Z. Cai, J. Zhang, W. Xu, D. Wen, H. Yin, Clear cell renal cell carcinoma: CT-based radiomics features for the prediction of Fuhrman grade, Eur. J. Radiol. 109 (2018) 8-12, https://doi.org/10.1016/j. ejrad.2018.10.005.

98] A. Bhandari, M. Ibrahim, C. Sharma, R. Liong, S. Gustafson, M. Prior, CT-based radiomics for differentiating renal tumours: a systematic review, Abdom. Radiol. (NY) 2 (2020), https://doi.org/10.1007/s00261-020-02832-9.

99] MG Lubner, Radiomics and artificial intelligence for renal mass characterization, Radiol. Clin. North Am. 58 (2020) 995-1008, https://doi.org/10.1016/j. rcl.2020.06.001.

100] A. Finelli, N. Ismaila, B. Bro, P. Russo, Management of small renal masses: american society of clinical oncology clinical practice guideline, J. Clin. Oncol. 35 (2017) 668-680, https://doi.org/10.1200/JOP.2016.019620. AC Tsili et al. European Journal of Radiology $141(2021) 10977713$

101] A. Vasudevan, RJ Davies, BA Shannon, RJ Cohen, Incidental renal tumours: the frequency of benign lesions and the role of preoperative core biopsy, BJU Int. 97 (2006) 946-949, https://doi.org/10.1111/j.1464-410X.2006.06126.x.

102] A. Sanchez, AS Feldman, A. Ari Hakimi, Current management of small renal masses, including patient selection, renal tumor biopsy, active surveillance, and thermal ablation, J. Clin. Oncol. 36 (2018) 3591-3600, https://doi.org/10.1200/ JCO.2018.79.2341.

103] K. Nakashima, Y. Kitagawa, K. Izumi, A. Mizokami, T. Gabata, M. Namiki, Diagnostic accuracy of pre-operative imaging findings in presumed clinical T1a renal cell carcinomas, Oncol. Lett. 11 (2016) 3189-3193, https://doi.org/ 10.3892/ol.2016.4330.

104] AJ Bradley, L. MacDonald, S. Whiteside, RJ Johnson, VAC Ramani, Accuracy of preoperative CT T staging of renal cell carcinoma: which features predict advanced stage? Clin. Radiol. 70 (2015) 822-829, https://doi.org/10.1016/j. crad.2015.03.013.

105] W. Chen, L. Wang, Q. Yang, B. Liu, Y. Sun, Comparison of radiographic and pathologic sizes of renal tumors, Int. Braz. J. Urol. 39 (2013) 189-194, https:// doi.org/10.1590/S16775538.IBJU.2013.02.06.

106] SE Lee, WK Lee, DS Kim, SH Doo, HZ Park, CY Yoon, SI Hwang, HJ Lee, G. Choe, SK Hong, Comparison of radiographic and pathologic sizes of renal tumors, World J. Urol. 28 (2010) 263-267, https://doi.org/10.1007/s00345-010- 0511-0.

107] C. Catalano, F. Fraioli, A. Laghi, A. Napoli, F. Pediconi, M. Danti, P. Nardis, R. Passariello, High-resolution multidetector CT in the preoperative evaluation of patients with renal cell carcinoma, AJR Am. J. Roentgenol. $180 \quad$ (2003) 1271-1277, https://doi.org/10.2214/ajr.180.5.1801271.

108] HK Sokhi, WY Mok, U. Patel, Stage T3a renal cell carcinoma: staging accuracy of CT for sinus fat, perinephric fat or renal vein invasion, Br. J. Radiol. 88 (2015) 20140504, https://doi.org/10.1259/bjr.20140504.

109] PJ Hallscheidt, M. Bock, G. Riedasch, I. Zuna, SO Schoenberg, F. Autschbach, M. Soder, G. Noeldge, Diagnostic accuracy of staging renal cell carcinomas using multidetector-row computed tomography and magnetic resonance imaging: a prospective study with histopathologic correlation, J. Comput. Assist. Tomogr. 28 (2004) 333-339, https://doi.org/10.1097/00004728-200405000-00005.

110] PJ Hallscheidt, C. Fink, A. Haferkamp, M. Bock, A. Luburic, I. Zuna, G. Noeldge, G. Kauffmann, Preoperative staging of renal cell carcinoma with inferior vena cava thrombus using multi- detector CT and MRI: prospective study with histopathological correlation, J. $\begin{array}{lllll}\text { Comput. } & \text { Assist. } & \text { Tomogr. } & 29 & \text { (2005) 64-68, }\end{array}$ https://doi.org/10.1097/01.rct.0000146113.56194.6d. 
111] N. Lawrentschuk, J. Gani, R. Riordan, S. Esler, DM Bolton, Multidetector computed tomography vs magnetic resonance imaging for defining the upper limit of tumour thrombus in renal cell carcinoma: a study and review, BJU Int. 96 (2005) 291-295, https://doi.org/10.1111/j.1464-410X.2005.05617.x.

112] Y. Sawai, T. Kinouchi, M. Mano, N. Meguro, O. Maeda, M. Kuroda, M. Usami, Ipsilateral adrenal involvement from renal cell carcinoma: retrospective study of the predictive value of computed tomography, Urology 59 (2002) 28-31, https:// doi.org/10.1016/s00904295(01)01480-7.

113] GJ Nason, A. Aslam, SK Giri, Predictive ability of preoperative CT scan in determining whether the adrenal gland is spared at radical nephrectomy, Curr. Urol. 9 (2016) 143-147, https://doi.org/10.1159/000442869.

114] S. Sheth, JC Scatarige, KM Horton, FM Corl, EK Fishman, Current concepts in the diagnosis and management of renal cell carcinoma: role of multidetector ct and three-dimensional CT, $\begin{array}{llll}\text { Radiographics } & 21 & \text { (2001) S237-S254, https:/doi.org/ }\end{array}$ 10.1148/radiographics.21.suppl_1.g01oc18s237.

115] N. Griffin, ME Gore, SA Sohaib, Imaging in metastatic renal cell carcinoma, AJR Am. J. Roentgenol. 189 (2007) 360-370, https://doi.org/10.2214/ AJR.07.2077.

116] DM Coll, BR Herts, WJ Davros, RG Uzzo, AC Novick, Preoperative use of 3D volume rendering to demonstrate renal tumors and renal anatomy, Radiographics 20 (2000) 431438, https://doi.org/10.1148/radiographics.20.2.g00mc16431.

117]F. Rocco, LA Cozzi, G. Cozzi, Study of the renal segmental arterial anatomy with contrastenhanced multi-detector computed tomography, Surg. Radiol. Anat. 37 (2015) 517-526, https://doi.org/10.1007/s00276-014-1382-7.

118] S. Donat, M. Diaz, J. Bishoff, JA Coleman, P. Dahm, IH Derweesh, S. Duke Herrell 3rd, S. Hilton, E. Jonasch, DW Lin, VE Reuter, SS Chang, Follow-up for clinically localized renal neoplasms AUA guideline, J. Urol. $190 \quad$ (2013) 407-416, https://doi.org/10.1016/j.juro.2013.04.121.

119] ESUR Guidelines on Contrast Agents v.10, European Society of Urogenital Radiology, 2021. www.esur-cm.org.

120] ZJ Wang, MS Davenport, SG Silverman, H. Chandarana, A. Doshi, GM Israel, JR Leyendecker, I. Pedrosa, S. Raman, EM Remer, AB Shinagare, AD Smith, R. Vikram, MRI Renal Mass Protocol v1.0: Society of Abdominal Radiology Disease Focused Panel on Renal Cell Carcinoma, 2020 https://doi.org/ abdominalradiology.org/wpcontent/uploads/2020/11/RCC.MRIprotocolfinal-7- 15-17.pdf.

121] GM Israel, N. Hindman, MA Bosniak, Evaluation of cystic renal masses: comparison of CT and MR imaging by using the Bosniak classification system, Radiology 231 (2004) 365371, https://doi.org/10.1148/radiol.2312031025.

122] AB Rosenkrantz, NE Wehrli, TC Mussi, SS Taneja, MJ Triolo, Complex cystic renal masses: comparison of cyst complexity and Bosniak classification between $1.5 \mathrm{~T}$ and $3 \mathrm{~T}$ MRI, Eur. J. Radiol. 83 (2014) 503-508, https://doi.org/ 10.1016/j.ejrad.2013.11.013.

123] NM Hindman, Imaging of cystic renal masses, Urol. Clin. North Am. 45 (2018) 331-349, https://doi.org/10.1016/j.ucl.2018.03.006.

124] JR Tse, J. Shen, L. Shen, L. Yoon, A. Kamaya, Bosniak classification of cystic renal masses version 2019: comparison of categorization using CT and MRI, AJR Am. J. Roentgenol. 216 (2021) 412-420, https://doi.org/10.2214/ AJR.20.23656.

125] M. Dilauro, M. Quon, MD McInnes, M. Vakili, A. Chung, TA Flood, N. Schieda, Comparison of contrast- enhanced multiphase renal protocol CT versus MRI for diagnosis of papillary renal cell carcinoma, AJR Am. J. Roentgenol. 206 (2016) 319-325, https://doi.org/10.2214/AJR.15.14932.

126] N. Schieda, RS Lim, MDF McInnes, I. Thomassin, R. Renard-Penna, S. Tavolaro, FH Cornelis, Characterization of small $(<4 \mathrm{~cm})$ solid renal masses by computed tomography and magnetic resonance imaging: current evidence and further development, Diagn. Interv. Imaging 99 (2018) 443-455, https://doi.org/ 10.1016/j.diii.2018.03.004.

127] F. Cornelis, E. Tricaud, AS Lasserre, F. Petitpierre, JC Bernhard, Y. Le Bras, M. Yacoub, M. Bouzgarrou, A. Ravaud, N. Grenier, Routinely performed multiparametric magnetic resonance imaging helps to differentiate common subtypes of renal tumours, Eur. Radiol. 24 (2014) 1068-1080, https://doi.org/ 10.1007/s00330-014-3107-z.

128] NK Ramamurthy, B. Moosavi, MD McInnes, TA Flood, N. Schieda, Multiparametric MRI of solid renal masses: pearls and pitfalls, Clin. Radiol. 70 (2015) 304-316, https://doi.org/10.1016/j.crad.2014.10.006. 
129] MR Sun, L. Ngo, EM Genega, MB Atkins, ME Finn, NM Rofsky, I. Pedrosa, Renal cell carcinoma: dynamic contrast-enhanced MR imaging for differentiation of tumor subtypescorrelation with pathologic findings, Radiology $250 \quad$ (2009) 793-802, https://doi.org/10.1148/radiol.2503080995.

130] JR Young, H. Coy, HJ Kim, M. Douek, P. Lo, AJ Pantuck, SS Raman, Performance of relative enhancement on multiphasic MRI for the differentiation of clear cell renal cell carcinoma (RCC) from papillary and chromophobe RCC subtypes and oncocytoma, AJR Am. J. Roentgenol. 208 (2017) 812-819, https:// doi.org/10.2214/AJR.16.17152.

131] AB Rosenkrantz, NE Wehrli, J. Melamed, SS Taneja, MB Shaikh, Renal masses measuring under $2 \mathrm{~cm}$ : pathologic outcomes and associations with MRI features, Eur. J. Radiol. 83 (2014) 1311-1316, https://doi.org/10.1016/j. ejrad.2014.05.016.

132] AM Hotker, Y. Mazaheri, A. Wibmer, CA Karlo, J. Zheng, CS Moskowitz, SK Tickoo, P. Russo, H. Hricak, O. Akin, Differentiation of clear cell renal cell carcinoma from other renal cortical tumors by use of a quantitative multiparametric MRI approach, AJR Am. J. Roentgenol. 208 (2017) W85-W91, https://doi.org/10.2214/AJR.16.16652.

133] C. Roy Sr, S. El Ghali, X. Buy, XV Lindner, H. Lang, C. Saussine, D. Jacqmin, Significance of the pseudocapsule on MRI of renal neoplasms and its potential application for local staging: a retrospective study, AJR Am. J. Roentgenol. 184 (2005) 113-120, https://doi.org/10.2214/ajr.184.1.01840113.

134] RS Lim, TA Flood, MDF McInnes, LT Lavallee, N. Schieda, Renal angiomyolipoma without visible fat: can we make the diagnosis using CT and MRI? Eur. Radiol. 28 (2018) 542-553, https://doi.org/10.1007/s00330-017- 4988-4.

135] FU Kay, NE Canvasser, Y. Xi, DF Pinho, DN Costa, A. Diaz de Leon, G. Khatri, JR Leyendecker, T. Yokoo, AH Lay, N. Kavoussi, E. Koseoglu, JA Cadeddu, I. Pedrosa, Diagnostic performance and interreader agreement of a standardized MR imaging approach in the prediction of small renal mass histology, Radiology 287 (2018) 543-553, https://doi.org/10.1148/radiol.2018171557.

136] C. Roy, B. Sauer, V. Lindner, H. Lang, C. Saussine, D. Jacqmin, MR Imaging of papillary renal neoplasms: potential application for characterization of small renal masses, Eur. Radiol. 17 (2007) 193-200, https://doi.org/10.1007/s00330-006-0271-9.

137] MR Oliva, JN Glickman, KH Zou, SY Teo, KJ Mortel’e, MS Rocha, SG Silverman, Renal cell carcinoma T1 and T2 signal intensity characteristics of papillary and clear cell types correlated with pathology, AJR Am. J. Roentgenol. 192 (2009) 1524-1530, https://doi.org/10.2214/AJR.08.1727.

138] JJ Park, CK Kim, Small $(<4 \mathrm{~cm})$ renal tumors with predominantly low signal intensity on T2-Weighted images: differentiation of minimal-fat angiomyolipoma from renal cell carcinoma, AJR Am. J. Roentgenol. 208 (2017) 124-130, https:// doi.org/10.2214/AJR.16.16102

139] C. Galmiche, JC Bernhard, M. Yacoub, A. Ravaud, N. Grenier, F. Cornelis, Is Multiparametric MRI Useful for Differentiating Oncocytomas From Chromophobe Renal Cell Carcinomas? AJR Am. J. Roentgenol. 208 (2017) 343-350, https://doi. org/10.2214/AJR.16.16832.

140] EA Lassel, R. Rao, C. Schwenke, SO Schoenberg, HJ Michaely, Diffusionweighted imaging of focal renal lesions: a meta-analysis, Eur. Radiol. 24 (2014) 241-249, https://doi.org/10.1007/s00330-013-3004-X.

141] M. Tordjman, R. Mali, G. Madelin, V. Prabhu, SK Kang, Diagnostic test accuracy of ADC values for identification of clear cell renal cell carcinoma: systematic review and metaanalysis, Eur. Radiol. 30 (2020) 4023-4038, https://doi.org/ 10.1007/s00330-020-06740-w.

142] A. Goyal, R. Sharma, AS Bhalla, S. Gamanagatti, A. Seth, VK Iyer, P. Das, Diffusionweighted MRI in renal cell carcinoma: a surrogate marker for predicting nuclear grade and histological subtype, Acta Radiol. 53 (2012) 349-358, https:// doi.org/10.1258/ar.2011.110415.

143] X. Yu, M. Lin, H. Ouyang, C. Zhou, H. Zhang, Application of ADC measurement in characterization of renal cell carcinomas with different pathological types and grades by 3.0T diffusion-weighted MRI, Eur. J. Radiol. 81 (2012) 3061-3066, https://doi.org/10.1016/j.ejrad.2012.04.028.

144] E. Inci, E. Hocaoglu, S. Aydin, T. Cimilli, Diffusion-weighted magnetic resonance imaging in evaluation of primary solid and cystic renal masses using the Bosniak classification, Eur. J. Radiol. 81 (2012) 815-820, https://doi.org/10.1016/j. ejrad.2011.02.024. AC Tsili et al. European Journal of Radiology 141 (2021) 10977714 
145] S. Sevcenco, G. Heinz-Peer, L. Ponhold, D. Javor, FE Kuehhas, HC Klingler, M. Remzi, P. Weibl, SF Shariat, PA Baltzer, Utility and limitations of 3-Tesla diffusion-weighted magnetic resonance imaging for differentiation of renal tumors, Eur. J. Radiol. 83 (2014) 909-913, https://doi.org/10.1016/j. ejrad.2014.02.026.

146] KM Krajewski, AB Shinagare, Novel imaging in renal cell carcinoma, Curr. Opin. Urol. 26 (2016) 388-395, https://doi.org/10.1097/ MOU.0000000000000314.

147] Y. Ding, Q. Tan, W. Mao, D. Chenchen, H. Xiaoyi, H. Jun, Z. Mengsu, Z. Jianjun, Differentiating between malignant and benign renal tumors: do IVIM and diffusion kurtosis imaging perform better than DWI? Eur. Radiol. 29 (2019) 6930-6939, https://doi.org/10.1007/s00330-019-06240-6.

148] A. Goyal, A. Razik, D. Kandasamy, A. Seth, P. Das, B. Ganeshan, R. Sharma, Role of MR texture analysis in histological subtyping and grading of renal cell carcinoma: a preliminary study, Abdom. Radiol. (NY) 44 (2019) 3336-3349, https://doi.org/10.1007/s00261-01902122-z.

149] JH Min, CK Kim, BK Park, E. Kim, B. Kim, Assessment of renal lesions with blood oxygenation level dependent MRI at $3 \mathrm{~T}$ : preliminary experience, AJR Am. J. Roentgenol. 197 (2011) W489-W494, https://doi.org/10.2214/AJR.10.6319.

150] W. Wang, K. Cao, S. Jin, X. Zhu, J. Ding, W. Peng, Differentiation of renal cell carcinoma subtypes through MRI-based radiomics analysis, Eur. Radiol. 57 (2020) 5738-5747, https://doi.org/10.1007/s00330-020-06896-5.

151] E. Cui, Z. Li, C. Ma, Q. Li, Y. Lei, Y. Lan, J. Yu, Z. Zhou, R. Li, W. Long, F. Lin, Predicting the ISUP grade of clear cell renal cell carcinoma with multiparametric MR and multiphase CT radiomics, Eur. Radiol. 30 (2020) 2912-2921, https://doi. org/10.1007/s00330-01906601-1.

152] HA Ali, MJ Couch, R. Menezes, AJ Evans, A. Finelli, MA Jewett, KS Jhaveri, Predictive value of in vivo MR spectroscopy with semilocalization by adiabatic selective refocusing in differentiating clear cell renal cell carcinoma from other subtypes, AJR Am. J. Roentgenol. 214 (2020) 817-824, https://doi.org/10.2214/ AJR.19.22023.

153] R. Papalia, V. Panebianco, R. Mastroianni, M. Del Monte, E. Altobelli, E. Faiella, FR Grasso, M. Bellangino, G. Simone, M. Ciccozzi, S. Angeletti, G. D'ovidio, C. Catalano, M. Gallucci, RM Scarpa, G. Muto, Accuracy of magnetic resonance imaging to identify pseudocapsule invasion in renal tumors, World J. Urol. 38 (2020) 407-415, https://doi.org/10.1007/s00345-019-02755-1.

154] LC Adams, B. Ralla, YY Bender, K. Bressem, B. Hamm, J. Busch, F. Fuller, MR Makowski, Renal cell carcinoma with venous extension: prediction of inferior vena cava invasion by MRI, Cancer Imaging 18 (2018) 17, https://doi.org/ 10.1186/s40644-018-0150-z.

155] ME Krokidis, P. Kitrou, S. Spiliopoulos, K. Karnabatidis, K. Katsanos, Imageguided minimally invasive treatment for small renal cell carcinoma, Insights Imaging 9 (2018) 385390, https://doi.org/10.1007/s13244-018-0607-4.

156] M. Rossi, G. Orgera, A. Hatzidakis, M. Krokidis, Minimally invasive ablation treatment for locally advanced pancreatic adenocarcinoma, Cardiovasc. Intervent. Radiol. 37 (2014) 586591, https://doi.org/10.1007/s00270-013- 0724-x.

157] DA Gervais, FJ McGovern, BJ Wood, SN Goldberg, WS McDougal, PR Mueller, Radiofrequency ablation of renal cell carcinoma: early clinical experience, Radiology 217 (2000) 665-672, https://doi.org/10.1148/ radiology.217.3.r00dc39665.

158]LW Organ, Electrophysiologic principles of radiofrequency lesion making, Appl. Neurophysiol. 39 (1976) 69-76, https://doi.org/10.1159/000102478 (1976- 1977).

159] SP Psutka, AS Feldman, WS McDougal, FJ McGovern, P. Mueller, DA Gervais, Long-term oncologic outcomes after radiofrequency ablation for T1 renal cell carcinoma, Eur. Urol. 63 (2013) 486-492, https://doi.org/10.1016/j. eururo.2012.08.062.

160] B. Feng, P. Liang, Local thermal ablation of renal cell carcinoma, Eur. J. Radiol. 81 (2012) 437-440, https://doi.org/10.1016/j.ejrad.2010.12.056.

161] NE Hoffmann, JC Bischof, The cryobiology of cryosurgical injury, Urology 60 (2002) 4049, https://doi.org/10.1016/s0090-4295(02)01683-7.

162] CS Georgiades, R. Rodriguez, Efficacy and safety of percutaneous cryoablation for stage 1A/B renal cell carcinoma: results of a prospective, single-arm, 5-year study, Cardiovasc. Intervent. Radiol. 37 (2014) 1494-1499, https://doi.org/ 10.1007/s00270-013-0831-8.

163] T. Kawabata, T. Hiraki, T. Iguchi, Y. Matsui, M. Uka, Y. Masaoka, T. Komaki, J. Sakurai, H. Gobara, M. Araki, Y. Nasu, S. Kanazawa, Post-ablation syndrome after percutaneous cryoablation of small renal tumors: a prospective study of incidence, severity, duration, and 
effect on lifestyle, Eur. J. Radiol. $122 \quad$ (2020) 108750, https://doi.org/10.1016/j.ejrad.2019.108750.

164] J. Yu, G. Zhang, P. Liang, Xl. Yu, Z. Cheng, Z. Han, X. Zhang, J. Dong, Q. Li, M. Mu, X. $\mathrm{Li}$, Midterm results of percutaneous microwave ablation under ultrasound guidance versus retroperitoneal laparoscopic radial nephrectomy for small renal cell carcinoma, Abdom. Imaging 40 (2015) 3248-3256, https://doi. org/10.1007/s00261-015-0500-2.

165] M. Allasia, F. Soria, A. Battaglia, C. Gazzera, M. Calandri, MP Caprino, B. Lucatello, A. Velrti, M. Maccario, B. Pasini, A. Bosio, P. Gontero, P. Destefanis, Radiofrequency ablation for renal Cancer in von hippel-lindau syndrome patients: a prospective cohort analysis, Clin. Genitourin. Cancer 10 (2017), https://doi. org/10.1016/j.clgc.2017.07.027. S15587673(17)30237-30239.

166] M. Krokidis, S. Spiliopoulos, M. Jarzabek, N. Fotiadis, T. Sabharwal, T. O'Brien, A. Adam, Percutaneous radiofrequency ablation of small renal tumours in patients with a single functioning kidney: long-term results, Eur. Radiol. 23 (2013) 1933-1939, https://doi.org/10.1007/s00330-013-2802-5.

167] R. Hoffmann, TF Jakobs, CH Kubisch, C. Trumm, C. Weber, M. Siebels, TK Helmberger, MF Reiser, Renal cell carcinoma in patients with a solitary kidney after nephrectomy treated with radiofrequency ablation: mid term results, Eur. J. Radiol. 73 (2010) 652-656, https://doi.org/10.1016/j.ejrad.2008.12.015.

168] S. Mylona, A. Kokkinaki, M. Pomoni, P. Galani, S. Ntai, L. Thanos, Percutaneous radiofrequency ablation of renal cell carcinomas in patients with solitary kidney: 6 years experience, Eur. J. Radiol. 69 (2009) 351-356, https://doi.org/10.1016/j. ejrad.2007.10.004.

169] A. Uhlig, O. Hahn, A. Strauss, J. Lotz, L. Trojan, R. Müller-Wille, J. Uhlig, Treatment for localized T1 a clear cell renal cell carcinoma: survival benefit for cryosurgery and thermal ablation compared to deferred therapy, Cardiovasc. Intervent. Radiol. 41 (2018) 277-283, https://doi.org/10.1007/s00270-017-1816-9.

170] R. El Dib, NJ Touma, A. Kapoor, Cryoablation vs radiofrequency ablation for the treatment of renal cell carcinoma: a meta-analysis of case series studies, BJU Int. 110 (2012) 510-516, https://doi.org/10.1111/j.1464-410X.2011.10885.x.

171] DA Kunkle, RG Uzzo, Cryoablation or radiofrequency ablation of the small renal mass: a meta-analysis, Cancer 113 (2008) 2671-2680, https://doi.org/ 10.1002/cncr.23896.

172] TD Atwell, GD Schmit, SA Boorjian, J. Mandrekar, A. Nicholas Kurup, AJ Weisbrod, GK Chow, BC Leibovich, MR Callstrom, DE Patterson, CM Lohse, R. Houston Thompson, Percutaneous ablation of renal masses measuring $3.0 \mathrm{~cm}$ and smaller: comparative local control and complications after radiofrequency ablation and cryoablation, AJR Am. J. Roentgenol. 200 (2013) 461-466, https://doi.org/10.2214/AJR.12.8618.

173] NJ Hegarty, IS Gill, MM Desai, EM Remer, CM O'Malley, JH Kaouk, Probe-ablative nephron-sparing surgery: cryoablation versus radiofrequency ablation, Urology 68 (2006) 7-13, https://doi.org/10.1016/j. urology.2005.12.049.

174] AJ Gunn, NS Parikh, S. Bhatia, Society of interventional radiology quality improvement standards on percutaneous ablation in renal cell carcinoma, J. Vasc. Interv. Radiol. 31 (2020) 195-201, https://doi.org/10.1016/j.jvir.2019.11.004.

175] IJ Patel, S. Rahim, JC Davidson, SE Hanks, AL Tam, T. Gregory Walker, LR Wilkins, R. Sarode, I. Weinberg, Society of Interventional Radiology Consensus Guidelines for the Periprocedural management of thrombotic and bleeding risk in patients undergoing percutaneous image-guided interventions. Part II: recommendations: endorsed by the Canadian Association for Interventional Radiology and the Cardiovascular and Interventional Radiological Society of Europe, J. Vasc. Interv. Radiol. 30 (2019) 11681184, https://doi.org/10.1016/j. jvir.2019.04.017.

176] M. Krokidis, C. Tappero, D. Bogdanovic, K. Ziebarth, AC Stamm, Computed tomography guided navigation assisted percutaneous ablation of osteoid osteoma in a 7-year-old patient: the low dose approach, Skeletal Radiol. 46 (2017) 989-993, https://doi.org/10.1007/s00256017-2620-y.

177] A. Babaei Jandaghi, M. Lebady, AA Zamani, A. Heidarzadeh, A. Monfared, R. Pourghorban, A randomised clinical trial to compare coaxial and noncoaxial techniques in percutaneous core needle biopsy of renal parenchyma, Cardiovasc. Intervent. Radiol. 40 (2017) 106-111, https://doi.org/10.1007/s00270-016- 1466-3.

178] J. Garnon, RL Cazzato, J. Caudrelier, M. Nouri-Neuville, P. Rao, E. Boatta, N. Ramamurthy, G. Koch, A. Gangi, Adjunctive thermoprotection during percutaneous thermal ablation 
procedures: review of current techniques, Cardiovasc. Intervent. Radiol. 42 (2019) 344-357, https://doi.org/10.1007/ s00270-018-2089-7.

179] X. Li, P. Liang, J. Yu, Y. Xiao-Ling, L. Fang-Yi, C. Zhi-Gang, H. Zhi-Yu, Role of contrastenhanced ultrasound in evaluating the efficiency of ultrasound guided percutaneous microwave ablation in patients with renal cell carcinoma, Radiol. Oncol. 47 (2013) 398 404, https://doi.org/10.2478/raon-2013-0038.

180] HJ Lee, HJ Chung, HK Wang, SH Shen, YH Chang, CK Chen, HP Chou, YY Chiou, Evolutionary magnetic resonance appearance of renal cell carcinoma after percutaneous cryoablation, Br. J. Radiol. 89 (2016) 20160151, https://doi. org/10.1259/bjr.20160151.

181] CJ Weight, JH Kaouk, NJ Hegarty, EM Remer, CM O'Malley, BR Lane, IS Gill, AC Novick, Correlation of radiographic imaging and histopathology following cryoablation and radio frequency ablation for renal tumors, J. Urol. 179 (2008) 1277-1281, https://doi.org/10.1016/j.juro.2007.11.075.

182] TM Wah, HC Irving, W. Gregory, J. Cartledge, AD Joyce, PJ Selby, Radiofrequency ablation (RFA) of renal cell carcinoma (RCC): experience in 200 tumours, BJU Int. 113 (2014) 416-428, https://doi.org/10.1111/bju.12349. 